\title{
TECHNETIUM-99 BEHAVIOR IN SAVANNAH RIVER SITE HIGH LEVEL WASTE SLUDGES DURING WASTE PROCESSING
}

\author{
N. E. Bibler \\ T. L. Fellinger \\ D. T. Hobbs
}

April 2004 
This document was prepared in conjunction with work accomplished under Contract No. DE-AC09-96SR18500 with the U. S. Department of Energy.

\section{DISCLAIMER}

This report was prepared as an account of work sponsored by an agency of the United States Government. Neither the United States Government nor any agency thereof, nor any of their employees, makes any warranty, express or implied, or assumes any legal liability or responsibility for the accuracy, completeness, or usefulness of any information, apparatus, product or process disclosed, or represents that its use would not infringe privately owned rights. Reference herein to any specific commercial product, process or service by trade name, trademark, manufacturer, or otherwise does not necessarily constitute or imply its endorsement, recommendation, or favoring by the United States Government or any agency thereof. The views and opinions of authors expressed herein do not necessarily state or reflect those of the United States Government or any agency thereof.

This report has been reproduced directly from the best available copy.

Available for sale to the public, in paper, from: U.S. Department of Commerce, National Technical Information Service, 5285 Port Royal Road, Springfield, VA 22161, phone: (800) 553-6847, fax: (703) 605-6900

email: orders@ntis.fedworld.gov

online ordering: http://www.ntis.gov/help/index.asp

Available electronically at http://www.osti.gov/bridge

Available for a processing fee to U.S. Department of Energy and its contractors, in paper, from: U.S. Department of Energy, Office of Scientific and Technical Information, P.O. Box 62, Oak Ridge, TN 37831-0062,

phone: (865)576-8401,

fax: (865)576-5728

email: $\underline{\text { reports@ adonis.osti.gov }}$ 
Key Words:

Sludge Composition

Supernate Composition

Tc-99

Tank Farm

Retention:

Permanent

\title{
TECHNETIUM-99 BEHAVIOR IN SAVANNAH RIVER SITE HIGH LEVEL WASTE SLUDGES DURING WASTE PROCESSING
}

\author{
N. E. Bibler \\ T. L. Fellinger \\ D. T. Hobbs
}

April 2004 
This page was intentionally left blank 


\section{EXECUTIVE SUMMARY}

This report presents results of an in-depth study of the behavior of technetium-99 (Tc-99) during waste processing operations at Savannah River Site (SRS). Tc-99 is a long lived $\left(\mathrm{t}_{1 / 2}=2.1 \mathrm{E} 05\right.$ years $)$ radioactive fission product of $\mathrm{U}-235$. Its behavior during high level waste (HLW) processing is important to understand because Tc-99 can fractionate in the waste and appear in both the sludge and the salt tanks at SRS. Further it can also be soluble in groundwaters and thus is an important radionuclide that may dictate how much residual waste has to be removed from a waste tank to prepare it for permanent closure. Results are also presented for Pd-105, another important U-235 fission product. This fission product is stable, but it is important because it has a finite solubility in the sludge supernates in the HLW and is also used to calculate the concentration of the radionuclide Pd-107 that has to be reported in the Waste Acceptance Specifications to send HLW glass to a repository.

The HLW processing steps considered in this report are listed below.

- The initial caustic adjustment of the acidic waste streams generated in the SRS canyons to prepare the waste for storage in the mild steel tanks in the SRS Tank Farm. This adjustment precipitates waste elements that are insoluble in alkaline solutions and thus changes the waste to slurries that contain sludge solids and supernates.

- The operations in the SRS Tank Farm that wash the precipitated sludge solids and result in waste being stored in sludge and salt tanks. This includes not only the sludge washing that can occur during routine slurry transfers in the Tank Farm and but also the washing of the sludge slurries to prepare them for final immobilization in the Defense Waste Processing Facility (DWPF).

- The immobilization process itself in the DWPF that solidifies the solids into a stable borosilicate glass.

Results are also presented in this report concerning the dissolution of Tc-99 from HLW sludges by oxalic acid should it be used in tank cleaning operations to reduce the Tc-99 in a tank prior to closure of the tank.

The data presented in this study are taken from published reports and from tests performed during the course of this study. These tests included both simulated HLW doped with Tc-99 and tests preformed remotely in the Shielded Cells with several samples of actual radioactive HLW that contained Tc-99 and Pd-105 generated in the SRS reactors.

Conclusions from this study are summarized below.

- Studies with a simulated HLW acid solution doped with Tc-99 indicate that up to $71 \%$ of the Tc-99 remains soluble in the final caustic HLW solution after caustic adjustment and sludge washing. This Tc-99 would thus be in salt supernates in salt tanks rather than in the sludge solids in the sludge tanks. 
- Investigations of four actual HLW sludge slurries from the SRS Tank Farm indicate that 90 to $95 \%$ of the fission product Tc-99 that could have been in the sludge slurries based on insoluble fission products in the slurries is not in the sludge slurries. This Tc-99 either did not precipitate in the initial caustic adjustment to the HLW or had been removed from the sludge slurries during Tank Farm operations. This Tc-99 is apparently in the salt tanks. The 5 to $10 \%$ present in the sludge slurries includes the Tc-99 in both the sludge solids and their supernates. For Pd-105 results indicate that 36 to $78 \%$ of this fission product could be in the salt tanks.

- In a washed sludge slurry in a sludge tank, results of this study indicate that only $11 \%$ of the total Tc-99 in the tank and 24\% of the total Pd-105 in the tank are present in the supernate of the sludge solids. This is expected since most of the soluble portions of these two isotopes have already been removed by the decanting of the original sludge supernate in the initial sludge precipitation step and by the sludge washing in the SRS Tank Farm.

- As part of this study, a HLW sludge slurry was extensively washed to determine the maximum amount of Tc-99, Pd-105, and other sludge components could be removed from the sludge solids by washing with inhibited water (IW). Inhibited water is $0.015 \mathrm{M}$ $\mathrm{NaOH}$ and $\mathrm{NaNO}_{2}$ and is used in the final washing to prepare a sludge slurry for vitrification in the DWPF. Of the Tc-99 and Pd-105 in the slurry, only 56\% of each isotope could be removed. Results of this study confirmed that washing of the sludge solids with IW, removed only the sludge components that were already dissolved in the supernate. The mechanism for this was one of just continual dilution of the dissolved components with wash water and their removal with subsequent wash water additions.

- In the final waste processing operation, immobilization of the sludge into glass in the DWPF process, the primary mechanism for the loss of Tc-99 is volatilization at $1150^{\circ} \mathrm{C}$ from the melter. Results indicate that this loss is only $\sim 5 \%$ and thus, $\sim 95 \%$ of the Tc-99 in a sludge slurry being fed to the DWPF is retained in the glass for final disposal.

- If oxalic acid is used to chemically clean tanks in the tank closure operations, results of tests using three HLW sludges indicate that 35 to $75 \%$ of the Tc-99 can be dissolved from the sludge solids by treatment of the sludge with $0.9 \mathrm{M}$ oxalic acid for two hours at $80^{\circ} \mathrm{C}$. Results of a related study indicate that the effectiveness of oxalic acid can be enhanced by the addition of $0.5 \mathrm{vol} . \%$ hydrogen peroxide. 


\section{TABLE OF CONTENTS}

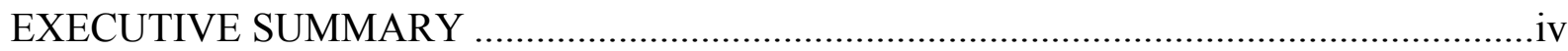

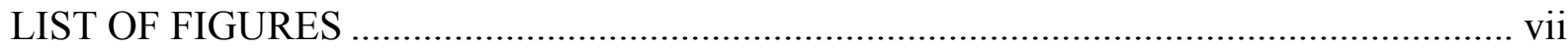

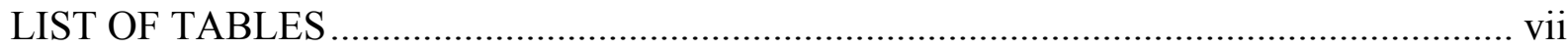

LIST OF ACRONYMS .............................................................................................. vii

1.0 INTRODUCTION AND BACKGROUND ……………..........................................

1.1 SUMMARY OF HLW MANAGEMENT PROCESSES AT SRS ....................................1

2.0 TESTS WITH A SIMULATED HLW SOLUTION DOPED WITH Te-99 .........................

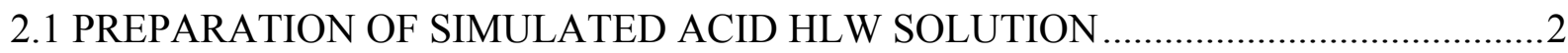

2.2 RINSING AND WASHING THE SLUDGE SOLIDS ................................................

2.3 FACTION OF Tc-99 IN THE SUPERNTE, RINSE, AND WASH SOLUTIONS AND THE FRACTION REMAINING IN THE SLUDGE SOLIDS .........................................

3.0 TESTS WITH RADIOACIVE HIGH LEVEL WASTE SLUDGES ...................................

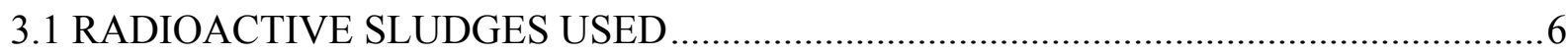

3.2 MEASURING THE COMPOSTIONOF THE SLUDGE SLURRY SAMPLES AND

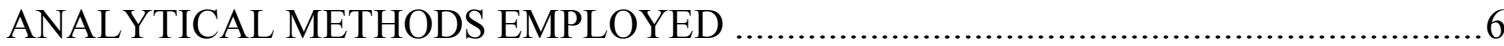

4.0 RESULTS AND DISCUSSION FOR TESTS USING RADIOACTIVE HIGHLEVEL

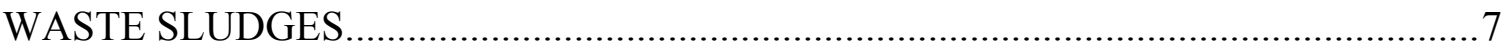

4.1 CALCULATION OF THE FRACTIONS OF TC-99 AND PD-105 REMOVED FROM THREE SLUDGE SLURRIES BY SRS HLW WASTE OPERATIONS ..........................

4.1.1 The Fission Yield Scaling Factor and Its Calculation ..............................................7

4.1.2 Measured and Predicted Concentrations of High Mass Fission Products in Sludge Batch Two and a Tank 7 Sample............................................................................ 10

4.1.3 Measured and Predicted Concentrations of Low Mass Fission Products in Sludge

Batch Two and a Tank 7 Sample...................................................................... 12

4.1.4 Calculation of the Fraction of Tc-99 and Pd-105 Removed from a Sample of Sludge Batch Two and a Sample of Tank 7 ..........................................................

4.2 FRACTION OF SOLUBLE AND INSOLUBLE Tc-99 AND Pd-105 IN A WASHED

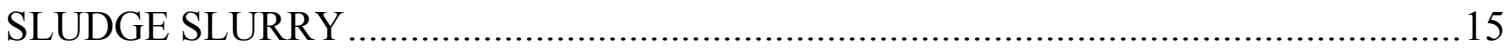

4.3 FRACTION OF Tc-99, Pd-105, AND OTHER SELECED ELEMENTS THAT COULD

BE REMOVED FROM AN UNWASHED SLURRY BY EXTENDED WASHING .....17

4.4 POSSIBLE LOSSES OF Tc-99 IN DWPF PROCESSING ………...............................22

4.5 DISSOLUTION OF Tc-99 FROM HLW SLUDGE BY OXALIC ACID FOR TANK

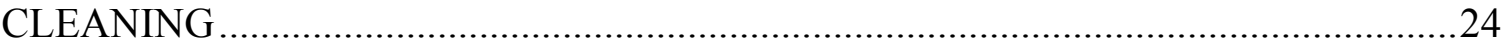

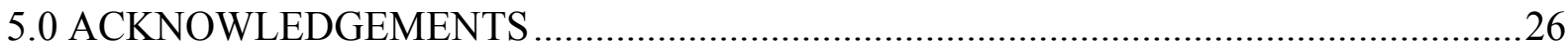

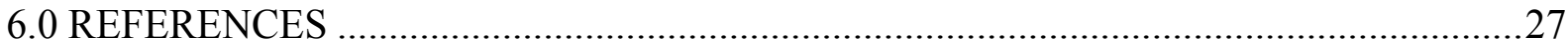




\section{LIST OF FIGURES}

Figure 2-1 Color Changes Observed during Caustic Precipitation of an Acidic Simulated High Level Waste Solution....

Figure 4-1 Fission Yields (in percent) as a Function of Atomic Mass Number for Slow Neutron

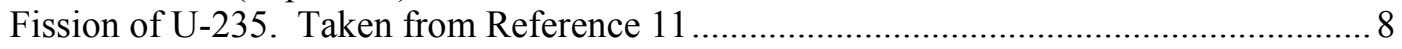

Figure 4-2 Measured and Predicted Concentrations for High Mass Fissions Products in the Tank 40

SB2 Sample

Figure 4-3 Measured and Predicted Concentrations for High Mass Fission Products in the Tank 40

Sludge Bathe Two Sample....

Figure 4-4 Measured and Predicted Concentrations for High Mass Fission Products in the Tank 40

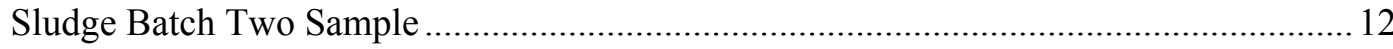

Figure 4-5 Measured and Predicted Concentrations for Low Mass Fission Products in the Tank 7

Sludge Sample ..................................................................................................... 13

Figure 4-6 Molar Concentrations in the Supernate and Wash Solutions of the Extended Washing of the Solids in a Sample of SB2 from Tank 40 ................................................................ 18

Figure 4-7 Color Changes Observed During Oxalic Acid Digestion of a Caustic Simulated High

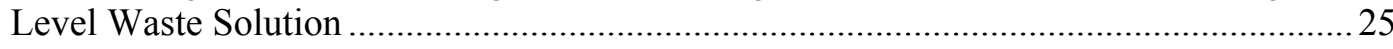

\section{LIST OF TABLES}

Table 2-1 Composition of a Simulated HLW Solution ................................................................... 2

Table 2-2 Fraction of Technetium in Supernate, Rinse Solutions, Wash Solutions and Insoluble Solids

Table 4-1 Calculated Values of the Fission Yield Scaling Factor (FYSF) ......................................... 9

Table 4-2 Fraction of Tc-99 and Pd-105 Removed from Tank 40 Sludge Batch 2 Slurry by SRS Tank

Farm Waste Management Process .............................................................................. 14

Table 4-3 Fraction of Tc-99 and Pd-105 Removed from Tank 7 Slurry by SRS Tank Farm Waste

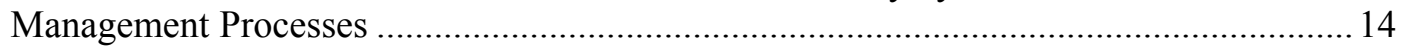

Table 4-4 Fraction of Tc-99 and Pd-105 Removed from a Tank 51 Slurry Sample of Sludge Batch 1B by SRS Tank Farm Waste Management Process ............................................................... 15

Table 4-5 Measured Quantities in Washed SB1B Necessary to Calculate Weight Fraction of Tc-99 and Pd-105 in the Total Dried Solids Based on the Tc-99 and Pd-105 in the Supernate of

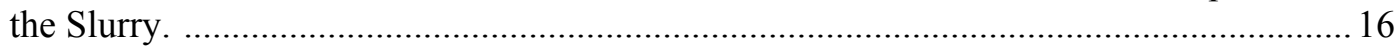

Table 4-6 Molar Concentrations in the Initial Supernate and the First Four Washed of the SB2 Sludge

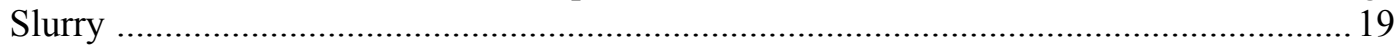

Table 4-7 Fractional Deceases in Each of the First Four Washes of the SB2 Sludge Slurry (a)......... 19

Table 4-8 Concentration of Elements Measured in the Unwashed and Totally Washed Solids of a

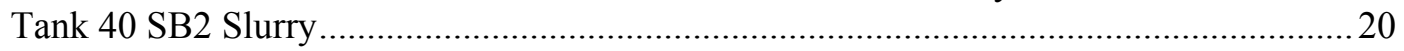

Table 4-9 Fractions of Elements Removed from a Tank 40 SB2 Slurry by Supernate Removal Followed by Extended Washing of the Solids .................................................................21

Table 4-10 Measured and Predicted Tc-99 Concentrations in Glass from DWPF Melter Pour Stream

Sampled During Filling of Three Canisters During SB1A Processing (a)........................2 23

Table 4-11 Fractions (Percent) of Tc-99, Na, Al, and Fe Dissolved from Samples of Dried Sludge

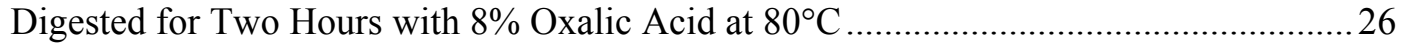




\section{LIST OF ACRONYMS}

$\begin{array}{ll}\text { ADS } & \text { Analytical Development Section } \\ \text { DWPF } & \text { Defense Waste Processing Facility } \\ \text { FY } & \text { Fission Yield } \\ \text { FYSF } & \text { Fission Yield Scaling Factor } \\ \text { HLW } & \text { High Level Waste } \\ \text { ICP-ES } & \text { Inductively Coupled Plasma - Emission Spectroscopy } \\ \text { ICP-MS } & \text { Inductively Coupled Plasma - Mass Spectroscopy } \\ \text { IW } & \text { Inhibited Water } \\ \text { SRS } & \text { Savannah River Site } \\ \text { SRTC } & \text { Savannah River Technology Center } \\ \text { SB1B } & \text { Sludge Batch 1B } \\ \text { SB2 } & \text { Sludge Batch 2 } \\ \text { SB3 } & \text { Sludge Batch 3 } \\ \text { WDF } & \text { Waste Dilution Factor }\end{array}$




\subsection{INTRODUCTION AND BACKGROUND}

Technetium-99 (Tc-99) is a U-235 fission product that was formed in the Savannah River Site (SRS) reactors during their operation. Essentially all of the Tc-99 produced in the reactors is present in the high level waste (HLW) at SRS. Tc-99 has a long half life (2.1E05 years [1]) and thus will be present in the wastes for centuries. It has been estimated that there are 3.1E04 Curies of Tc-99 in the HLW.[2] Tc-99 is of special interest because it can form two species in the wastes depending on the oxidation state of the Tc-99.[3] One species contains Tc-99 in the +4 state and is the oxide $\mathrm{TcO}_{2}$. This oxide exhibits very low solubility under alkaline conditions and thus precipitates with the HLW sludge solids when the acidic wastes from the SRS processes are made alkaline for long term storage in the mild steel tanks at SRS The other species contains Tc-99 in the +7 oxidation state. This is the pertechnetate anion, $\mathrm{TcO}_{4}{ }^{-}$, which is soluble in highly alkaline solutions. Pertechnetate is primary Tc-99 species in the waste supernates.

This report presents results of a study of the behavior of Tc-99 under conditions pertinent to the storage, retrieval, and processing of the HLW at SRS. Results are presented for both simulated HLW doped with Tc-99 and for several actual HLW radioactive sludges containing Tc-99 created in the SRS reactors. For the radioactive sludges some results are also presented for Pd105, another U-235 fission product of interest. This fission product is nonradioactive. However, it is of interest because it slightly soluble in HLW supernates and is used to calculate the concentration of $\mathrm{Pd}-107$, a radionuclide that is reportable for permanent disposal of the HLW because of the Waste Acceptance Product Specifications. [4] Palladium in the supernates of the HLW has also been shown to catalyze the decomposition of sodium tetraphenlyborate that was proposed to remove Cs-137 from the HLW supernates. [5]

Prior to presenting the results of this study, it is helpful to present a summary of the HLW management processes at SRS. These are neutralization of the acid waste, separation of the sludge and supernate, washing of the sludge solids, and finally immobilization of the sludge slurries for permanent disposal. These are summarized below.

\subsection{SUMMARY OF HLW MANAGEMENT PROCESSES AT SRS}

The high level waste streams that resulted from the various separation processes at SRS were primarily nitric acid solutions. Prior to caustic adjustment these are evaporated to remove water and recover as much of the nitric acid as possible. This produced some solids in the concentrated wastes in the evaporators. These solids and their supernates are then made caustic for long term storage in the mild steel tanks at SRS. During caustic addition more solids precipitated. Those fission products and process chemicals that are insoluble in caustic precipitate to form sludges. The soluble fission products remain in the supernatant liquid. Most of the supernate is decanted to another tank and then evaporated to reduce the volume requiring storage. The concentrated supernates are then transferred to tanks designated as salt tanks. The sludge solids are pumped as slurries to tanks designated as sludge tanks. Thus the sludge tanks contain the most of the insoluble fission products and the salt tanks contain most of the soluble fission products. Fractions of the various fission products that are in the sludge tanks and in the salt tanks have 
been estimated. For example it has been estimated that $95 \%$ of the Cs-137 in the salt tanks and that $99.9 \%$ of the Sr-90 is in the sludge tanks. [6] For Tc-99, it has been estimated that $\sim 60 \%$ resides in the salt tanks and $\sim 30$ percent in the sludge tanks. [2] Using results from the present study, it is possible to calculate this fraction for Tc-99 and Pd-105 based on the analysis of a sludge slurry. Results will be presented for several sludge slurries. Currently, as the final waste processing step, the sludge slurries from sludge tanks are being immobilized into a stable borosilicate glass for final geologic disposal. In the DWPF process, the primary mechanism for the loss of Tc-99 is volatilization at $1150^{\circ} \mathrm{C}$ from the DWPF melter because Tc-99 can form an oxide $\left(\mathrm{Tc}_{2} \mathrm{O}_{7}\right)$ that has a boiling point of only $311^{\circ} \mathrm{C}$. [3]

\subsection{TESTS WITH A SIMULATED HLW SOLUTION DOPED WITH Tc-99}

The results of the tests described in this section indicate that 70 to $80 \%$ of the technetium in an acidic HLW stream does not remain with the HLW sludge solids during after the caustic precipitation of the solids and their subsequent rinsing and washing in HLW processing operations. This range is higher than the fraction of 57\% estimated earlier. [2]

\subsection{PREPARATION OF SIMULATED ACID HLW SOLUTION}

To determine the fractionation of Tc-99 during the precipitation of the sludge solids from an acidic HLW salt solution, tests were performed starting with a simulated HLW solution doped with Tc-99. One hundred milliliters of solution were prepared using nitric acid and nitrate salts of the major components of the waste. A portion of the solution was doped with a known amount of Tc-99. Composition of the solution is given in Table 2-1. The final acidity of the solution was 2.0M.

Table 2-1 Composition of a Simulated HLW Solution

\begin{tabular}{||c|c|c||}
\hline Component & $\begin{array}{c}\text { Quantity per 100mL } \\
\text { Of Solution (grams) }\end{array}$ & Concentration (M) \\
\hline $\mathrm{Fe}\left(\mathrm{NO}_{3}\right)_{3} \cdot 9 \mathrm{H}_{2} \mathrm{O}$ & 13.961 & 0.346 \\
\hline $\mathrm{Al}\left(\mathrm{NO}_{3}\right)_{3} \cdot 9 \mathrm{H}_{2} \mathrm{O}$ & 4.185 & 0.112 \\
\hline $\mathrm{UO}_{2}\left(\mathrm{NO}_{3}\right)_{2} \cdot 6 \mathrm{H}_{2} \mathrm{O}$ & 2.426 & 0.0483 \\
\hline $\mathrm{CaCl}_{2}$ & 0.421 & 0.0379 \\
\hline $\mathrm{Ni}\left(\mathrm{NO}_{3}\right)_{2} \cdot 6 \mathrm{H}_{2} \mathrm{O}$ & 1.873 & 0.0644 \\
\hline $50 \mathrm{wt} \% \mathrm{Mn}\left(\mathrm{NO}_{3}\right)_{2}$ solution & 1.238 & 0.0692 \\
\hline $\mathrm{HNO} 3(15.9 \mathrm{M})$ & 17.9 & 2.0 \\
\hline
\end{tabular}


To dope the solution with Tc-99, exactly $65 \mu \mathrm{L}$ of a stock solution containing $7.22 \mathrm{E}+08 \mathrm{dpm} / \mathrm{mL}$ of Tc-99 was added to $25 \mathrm{~mL}$ of the acidic waste solution. The Tc-99 solution was obtained commercially. It had been prepared by dissolving solid $\mathrm{NH}_{4} \mathrm{TcO}_{4}$ in $0.5 \mathrm{M} \mathrm{HNO}_{3}$. Thus the initial form of the Tc-99 was the soluble pertechnetate anion as it is the acidic HLW salt solutions. This quantity of Tc-99 provides a Tc-99 concentration of $5.0 \mathrm{mg} / \mathrm{L}$ or $5.0 \mathrm{E}-05 \mathrm{M}$. The molar ratio of this concentration to that for $\mathrm{Fe}$ is only $\sim 5$ times greater that that in a typical actual SRS HLW salt solution; Thus the behavior of the Tc-99 in this solution should be similar to its behavior in a HLW solution.

Four tests were performed, each in a $40 \mathrm{~mL}$ centrifuge tube equipped with a Teflon ${ }^{\circledR}$-coated magnetic stirring bar. For each test a $1.0 \mathrm{~mL}$ aliquot of the acid solution was put into each tube. In Test 3 we added a stainless steel rod to determine if this might reduce the Tc to a lower oxidation and affect the fraction soluble. This rod remained in Test 3 until the completion of the test. Sufficient $50 \mathrm{wt} \% \mathrm{NaOH}$ solution was added to the each test solution to bring the final hydroxide concentration in each to much greater than $1.2 \mathrm{M}$, which is the minimum target for fresh HLW in the SRS processes. With stirring exactly $1.2 \mathrm{~mL}$ of $50 \mathrm{wt} \% \mathrm{NaOH}$ solution was added to Test 1 . in $0.10-\mathrm{mL}$ increments over a 30 minute period eventually producing a dark brown-black suspension. In Tests 2 though 4, the quantity of $50 \mathrm{wt} \% \mathrm{NaOH}$ added was $0.36 \mathrm{~mL}$, $0.28 \mathrm{~mL}$, and $0.28 \mathrm{~mL}$, respectively. These quantities of $\mathrm{Na} \mathrm{OH}$ solution should provide a final free hydroxide concentration of at least 1.2MThe final $\mathrm{pH}$ of each solution was $>12$ as measured by $\mathrm{pH}$ paper. We mixed the suspensions at ambient laboratory temperature overnight and then centrifuged for 45 minutes at which point we observed no further separation of the supernate and the solids. We pipetted the supernate from the settled solids into a clean plastic sample bottle for later analysis.

Shown below in Figure 2-1 are the color changes observed during the precipitation of $10 \mathrm{~mL}$ of the acidic waste solution with $12 \mathrm{~mL}$ of $50 \mathrm{wt} \% \mathrm{NaOH}$ solution. There was no Tc-99 in this solution. 
Before $\mathrm{NaOH}$ addition
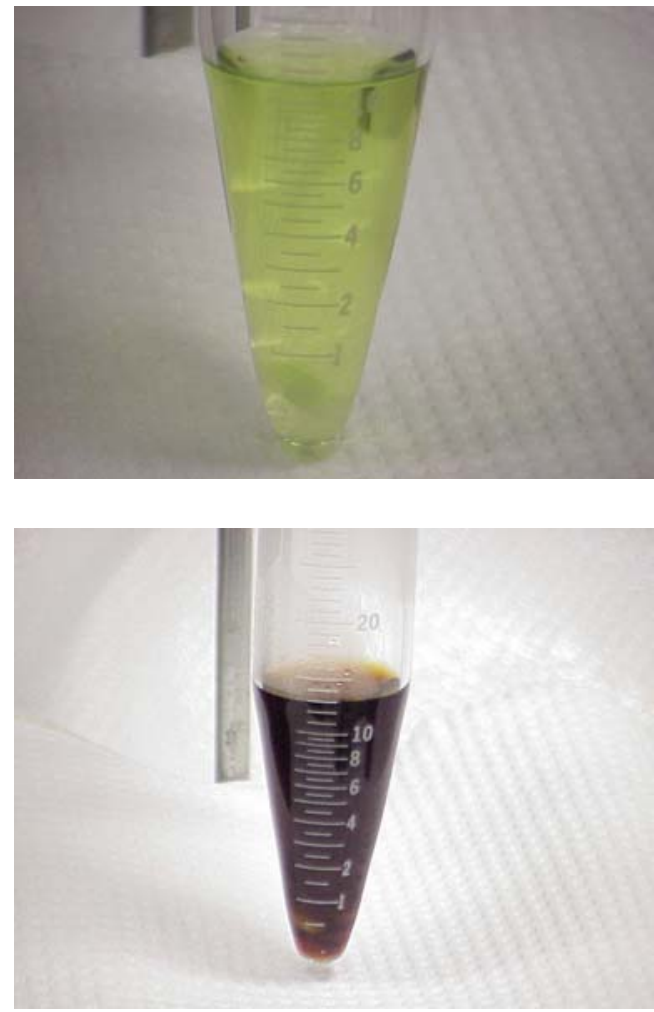

During early stage of $\mathrm{NaOH}$ addition
During very early stage of $\mathrm{NaOH}$ addition
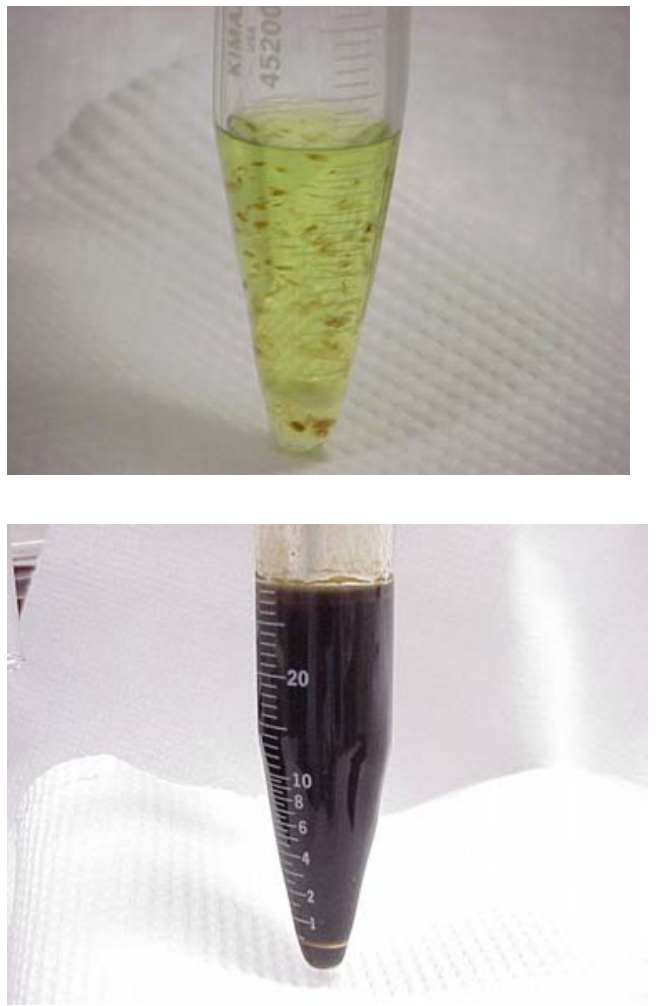

After complete addition of $\mathrm{NaOH}$

\section{Figure 2-1 Color Changes Observed during Caustic Precipitation of an Acidic Simulated} High Level Waste Solution

Initially the acidic solution is a pale green. Upon addition of sodium hydroxide, the solution becomes golden yellow with the precipitation of white and dark brown-black solids. We believe the white solids are principally a mixture of $\mathrm{Al}(\mathrm{OH})_{3}$ and $\mathrm{Mn}(\mathrm{OH})_{2}$. The darker solids are principally $\mathrm{Fe}(\mathrm{OH})_{3}$. The suspension then becomes darker with continued addition of $\mathrm{NaOH}$ resulting in a dark brown-black color. After centrifuging the mixture, the supernate is colorless and the solids are brownish black.

\subsection{RINSING AND WASHING THE SLUDGE SOLIDS}

We used a caustic salt solution ( $2 \mathrm{M} \mathrm{NaOH}$ and $2 \mathrm{M} \mathrm{NaNO}_{3}$ ) to rinse the solids to lower the concentration of caustic prior to washing the solids with dilute caustic. We added $5 \mathrm{~mL}$ of rinse to the solids in Test 1 and $1 \mathrm{~mL}$ to the solids in Tests 2-4. We agitated the solids for approximately five minutes. We then centrifuged the suspension and pipetted each rinse solution into a separate clean plastic sample bottle for later analysis. We repeated the solids rinsing one more time in Test 1 and two more times for the other three tests. These rinse solutions were combined with their respective prior rinse solutions. The rinse solutions were saved for later analysis for Tc-99. We then air dried the rinsed sludge solids in the centrifuge tubes. 
To simulate washing the sludge in the SRS Tank Farm, we used a dilute solution of $0.015 \mathrm{M}$ $\mathrm{NaOH}$ and $0.012 \mathrm{M} \mathrm{NaNO}_{2}$ referred to as inhibited water (IW). For the other three tests we used $1 \mathrm{~mL}$ of the wash solution. These were pipetted into the centrifuge tubes containing the air-dried sludge solids. We gently agitated the centrifuge tube for five minutes until all of the solids had been wetted with the wash solution. We then centrifuged the contents until observing a clear supernate liquid. We pipetted the supernatant liquid from the solids and placed the liquid in a clean plastic sample bottle. For each test we repeated the washing sequence four more times. All the wash solutions for each respective test were combined for analysis of Tc-99 in the solutions.

\subsection{FACTION OF Tc-99 IN THE SUPERNTE, RINSE, AND WASH SOLUTIONS AND THE FRACTION REMAINING IN THE SLUDGE SOLIDS}

We submitted aliquots of the initial supernates, the rinse solutions and the wash solutions to the Analytical Development Section (ADS) for determination of T-99 concentration in each solution by beta counting. Then the total amount of Tc-99 in each solution could be calculated knowing the total volume of the solution. The fraction of Tc-99 removed by that solution was then calculated by knowing the amount of Tc-99 added to each test.

Table 2-2 shows the results for the fraction of Tc-99 measured in the original supernate, the rinse solutions and in the wash solutions. The fraction of Tc-99 remaining in the sludge solids is the difference between the original total Tc in the acidic solution and the sum of the fractions removed in the supernate, rinse and wash solutions.

Table 2-2 Fraction of Technetium in Supernate, Rinse Solutions, Wash Solutions and Insoluble Solids

\begin{tabular}{||c|c|c|c|c|c||}
\hline \hline Test No. & Supernate & Rinse & Wash & $\begin{array}{c}\text { Fract. Not } \\
\text { In Solids }\end{array}$ & $\begin{array}{c}\text { Fract. } \\
\text { In Solids }\end{array}$ \\
\hline 1 & 0.35 & 0.11 & 0.25 & 0.71 & 0.29 \\
\hline 2 & 0.22 & 0.14 & 0.11 & 0.47 & 0.53 \\
\hline $3^{*}$ & 0.11 & 0.21 & 0.39 & 0.71 & 0.25 \\
\hline 4 & 0.46 & 0.21 & 0.12 & 0.79 & 0.21 \\
\hline
\end{tabular}

Results indicated that with the exception of Test 2, 70 to $80 \%$ of the original technetium in the acidic waste solution remained soluble or was readily separated from the sludge solids during the rinsing and washing steps. We do not have an explanation of the high fraction (0.53) of insoluble technetium in Test 2. The addition of a stainless steel rod in Test 3 appeared to reduce the amount of technetium in the original supernate. However, the Tc-99 was readily removed during subsequent rinses and washes of the sludge solids leaving only $28 \%$ of the technetium in the sludge solids. Thus, any change in the redox of the solution as a result of the presence of the stainless steel rod, did not form an irreversible, insoluble phase of Tc-99. 


\subsection{TESTS WITH RADIOACIVE HIGH LEVEL WASTE SLUDGES}

\subsection{RADIOACTIVE SLUDGES USED}

For this study we used four different radioactive HLW sludge samples. All the sludge samples are slurries comprised of insoluble solids and supernatant liquids that contain dissolve salts. The sludge slurry samples had been placed in the Shielded Cells of SRTC for characterization in preparation for their processing by the DWPF. Two of the sludge samples were obtained from the large sludge batches processed in the DWPF for immobilization into glass for final storage. These include Sludge Batch 1B (SB1B) from Tank 51 and Sludge Batch 2 (SB2) from Tank 40. These sludges had been washed in the in the Tank Farm to lower their Na content prior to their processing in the DWPF. Both of the samples had been characterized prior to our using them for this Tc-99 study. See Reference [7] for SB1B and Reference [8] for SB2. The third sludge slurry sample was an unwashed sample of SB2. We determined the composition of this sample to measure how much of selected waste components (including Tc-99) had been removed from this sample by HLW processing. The method of determining this composition will be discussed in Section 3.2. The fourth sludge sample that we used was a sludge slurry sample from Tank 7. The sludge slurry from this tank will be the principal component of Sludge Batch 3 (SB3) that will be fed to the DWPF from Tank 40. This sample was taken from Tank 7 in December 2002, soon after slurry pumps had been put into the tank and a portion of it mixed. The concentrations of major elements in this sample of Tank 7 have already been reported.[9] In this study we report the concentrations of Tc-99 and other U-235 fission products that were measured.

\subsection{MEASURING THE COMPOSTION OF THE SLUDGE SLURRY SAMPLES AND ANALYTICAL METHODS EMPLOYED}

For this study, the composition of a sludge slurry is given in terms of weight percent of an element in the total dried solids of an aliquot of the slurry. The slurry includes both the sludge solids and the caustic supernate of the solids. Aliquots of the thoroughly mixed slurries were dried and then dissolved remotely in the Shielded Cells of SRTC. Details have been published and will only be summarized here.[7,8]

Aliquots of the slurry were taken after the slurry was thoroughly mixed. Two to four aliquots were taken for each sludge slurry. These were dried and then dissolved using the Analytical Development Section (ADS) approved procedure for dissolving dried sludge solids by aqua regia.[10] The resulting solutions were analyzed by ADS for elemental and radionuclide content. An appropriate standard was also dissolved with the solids and analyzed to check the dissolutions and analytical methods. A blank solution was prepared to check for impurities that might be introduced during the dissolution methods. The dissolutions were performed

For this study, three analytical methods were used. The solutions were analyzed by Inductively Coupled Plasma - Emission Spectroscopy (ICP-ES) for the major nonradioactive elements. For U-235 fission products including Tc-99 and Pd-105, the solutions were analyzed by Inductively Coupled Plasma - Mass Spectroscopy (ICP-MS). Finally, the solutions were analyzed by gamma counting for Cs-137. 


\subsection{RESULTS AND DISCUSSION FOR TESTS USING RADIOACTIVE HIGHLEVEL WASTE SLUDGES}

\subsection{CALCULATION OF THE FRACTIONS OF Tc-99 AND Pd-105 REMOVED FROM THREE SLUDGE SLURRIES BY SRS HLW WASTE OPERATIONS}

Calculation of this fraction is based on the Fission Yield Scaling Factor (FYSF) determined for each of the three sludge slurries and the assumption that Tc-99 and Pd-105 are completely insoluble in the caustic waste solution. Three radioactive HLW slurries were. The fission yield scaling factor (FYSF) is a factor that allows the concentration of a fission product to be calculated based on its fission yield and atomic mass. Discussion of the factor will be presented first.

\subsubsection{The Fission Yield Scaling Factor and Its Calculation}

The fission yield scaling factor relates the concentration of a fission product in a sludge slurry to its fission yield and the atomic mass of that fission product. This factor can be used to calculate the fractions of Tc-99 and Pd-105 that had been removed from a sludge slurry by the HLW processing steps. This was done by comparing the measured concentrations of these two fission products in a sludge slurry to their predicted concentrations assuming they are completely insoluble and are present in the sludge solids. Prior to presenting the results of these calculations some background information is helpful.

The fission products in SRS high level waste primarily result from the fission of U-235 used in the SRS reactors to produce neutrons or from fission of the U-235 in the natural uranium irradiated in the reactors to produce $\mathrm{Pu}-239$. The relative amounts (fission yields) of these products occur in a low and a high mass fraction and their yields are well known from many studies. Values of these yields has been compiled and published.[1] Figure 4-1 shows the fission yields as a function of isotopic mass number. The fission yields are in terms of the number of atoms of that mass formed per 100 fissions of the U-235. Note there is a low mass fraction and a high mass fraction. 


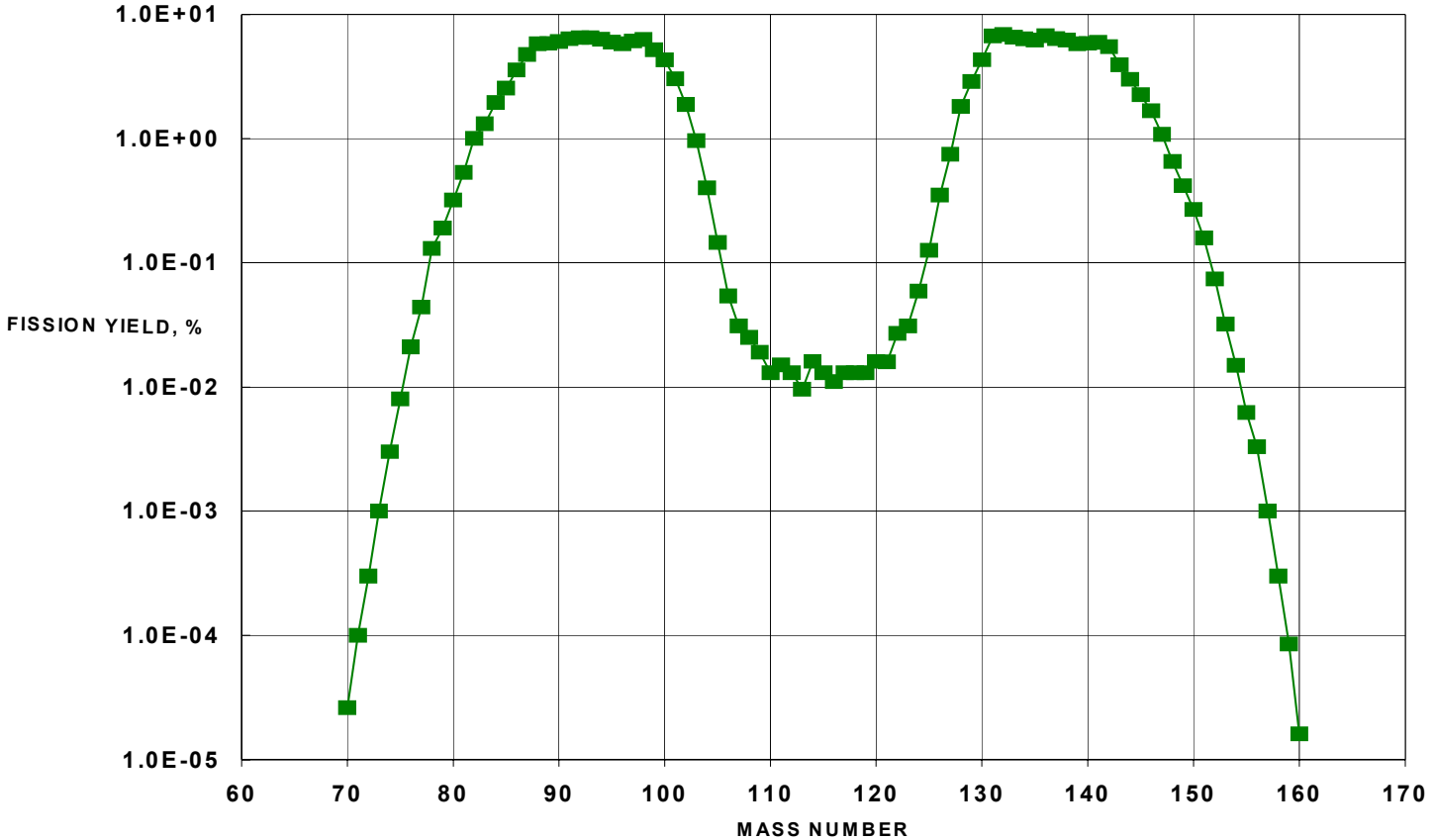

Figure 4-1 Fission Yields (in percent) as a Function of Atomic Mass Number for Slow Neutron Fission of U-235. Taken from Reference 11

Assignment of specific isotopes to these mass numbers is done by considering the half lives of the various radionuclides in the respective isobaric fission chains from fission of $\mathrm{U}-235$. The isotopes in each of these chains are originally neutron rich immediately after the fission. They then beta decay - increasing in atomic number while the atomic mass remains constant. In each chain usually the isotope with the longest half life is assigned to that mass. These assignments have been discussed in four other publications. [12-15]

As stated before, the FYSF relates the concentration of a fission The fission yields given in Figure 4-1 are terms of atoms produced per 100 fissions of U-235. Since the FYSF is defined in terms of weight percent of an isotope, the atomic mass of that isotope has to be included in the equation. The equation for the concentration is then

$$
\text { Concentration ( } \mathrm{wt} \%)=\mathrm{FYSF} \text { (fission yield } \mathrm{X} \text { atomic mass) }
$$

Thus the FYSF for each measured isotope can be calculated from the Equation 2.

$$
\mathrm{FYSF}=\mathrm{wt} \% /(\text { fission yield } \mathrm{X} \text { atomic mass) }
$$


For those isotopes that meet following five criteria the FYSF should be a constant. First, the isotopes have to have low solubilities in $\mathrm{NaOH}$ and thus occur predominantly in the sludge slurries rather than the supernates. Second, they need to be stable or have long half lives and thus have not decayed significantly since the waste was generated. Third, the isotopes have to have low neutron cross sections and thus were not transmuted in the SRS reactors during their operation. Third, the isotopes could not be formed in the reactors by neutron absorption. Fourth, the isotopes cannot be added to the waste from any of the processing chemicals used at SRS. Lastly, the isotopes have to have masses where spectral interferences from impurities in the Ar plasma or from oxides formed in the plasma of the ICP-MS do not create a problem.

Eleven U-235 fission products meet the above five criteria. These isotopes are $\mathrm{Ru}-101, \mathrm{Ru}-102$, Rh-103, La-139, Pr-141, Nd-143, 144, 145, 146, Sm-147, and Nd-148. Note that there are three isotopes from the low mass fraction in the fission yield curve and eight from the high mass fraction. The fission yield scaling factor for each of these isotopes was calculated using Equation 2. Results for SB2 are presented in Table 4-1. Based on earlier analyses and the chemistry of these isotopes it was estimated that $75 \%$ of the Ru and $>99 \%$ of the other elements listed in Table 4-1 should be in the sludge solids.[6]

Table 4-1 Calculated Values of the Fission Yield Scaling Factor (FYSF) Based on Eleven U-235 Fission Products in Sludge Batch Two in Tank 40 (a)

\begin{tabular}{||c|c|c|c||}
\hline \hline Isotope & Wt\% (b) & Fission Yield & FYSF \\
\hline Ru-101 & $1.32 \mathrm{E}-02$ & 5.18 & $2.5 \mathrm{E}-05$ \\
\hline Ru-102 & $1.20 \mathrm{E}-02$ & 4.29 & $2.7 \mathrm{E}-05$ \\
\hline Rh-103 & $7.77 \mathrm{E}-03$ & 3.03 & $2.5 \mathrm{E}-05$ \\
\hline La-139 & $2.10 \mathrm{E}-02$ & 6.60 & $2.3 \mathrm{E}-05$ \\
\hline Pr-141 & $1.84 \mathrm{E}-02$ & 5.90 & $2.2 \mathrm{E}-05$ \\
\hline Nd-143 & $1.89 \mathrm{E}-02$ & 6.00 & $2.2 \mathrm{E}-05$ \\
\hline Nd-144 & $1.95 \mathrm{E}-02$ & 5.45 & $2.5 \mathrm{E}-05$ \\
\hline Nd-145 & $1.31 \mathrm{E}-02$ & 3.95 & $2.3 \mathrm{E}-05$ \\
\hline Nd-146 & $1.11 \mathrm{E}-02$ & 3.00 & $2.5 \mathrm{E}-05$ \\
\hline Sm-147 & $7.86 \mathrm{E}-03$ & 2.26 & $2.4 \mathrm{E}-05$ \\
\hline Sm-148 & $6.86 \mathrm{E}-03$ & 1.69 & $2.8 \mathrm{E}-05$ \\
\hline Average & - & - & $2.4 \mathrm{E}-05$ \\
\hline
\end{tabular}

(a) Complete analytical results given in Reference 7.

(b) Weight percent in total dried solids of the slurry sample.

Note that the factors for the eleven isotopes are in good agreement. The average FYSF based on the eleven isotopes was $2.4 \mathrm{E}-05 \mathrm{wt} \% /$ (fission yield atomic mass) with a $7.7 \%$ RSD It is now possible to calculate the predicted concentration of any U-235 fission product in the SB2 slurry using this value for the FYSF, assuming that the isotope is insoluble in caustic and resides primarily in the sludge solids. 
Plots comparing measured and predicted concentrations for measured isotopes in the SB2 slurry and in the Tank 7 slurry are presented below.

\subsubsection{Measured and Predicted Concentrations of High Mass Fission Products in Sludge Batch Two and a Tank 7 Sample}

Figure 4-2 shows the measured concentrations and predicted concentrations of the high mass fission products detected and measured in the SB2 sample by ICP-MS.

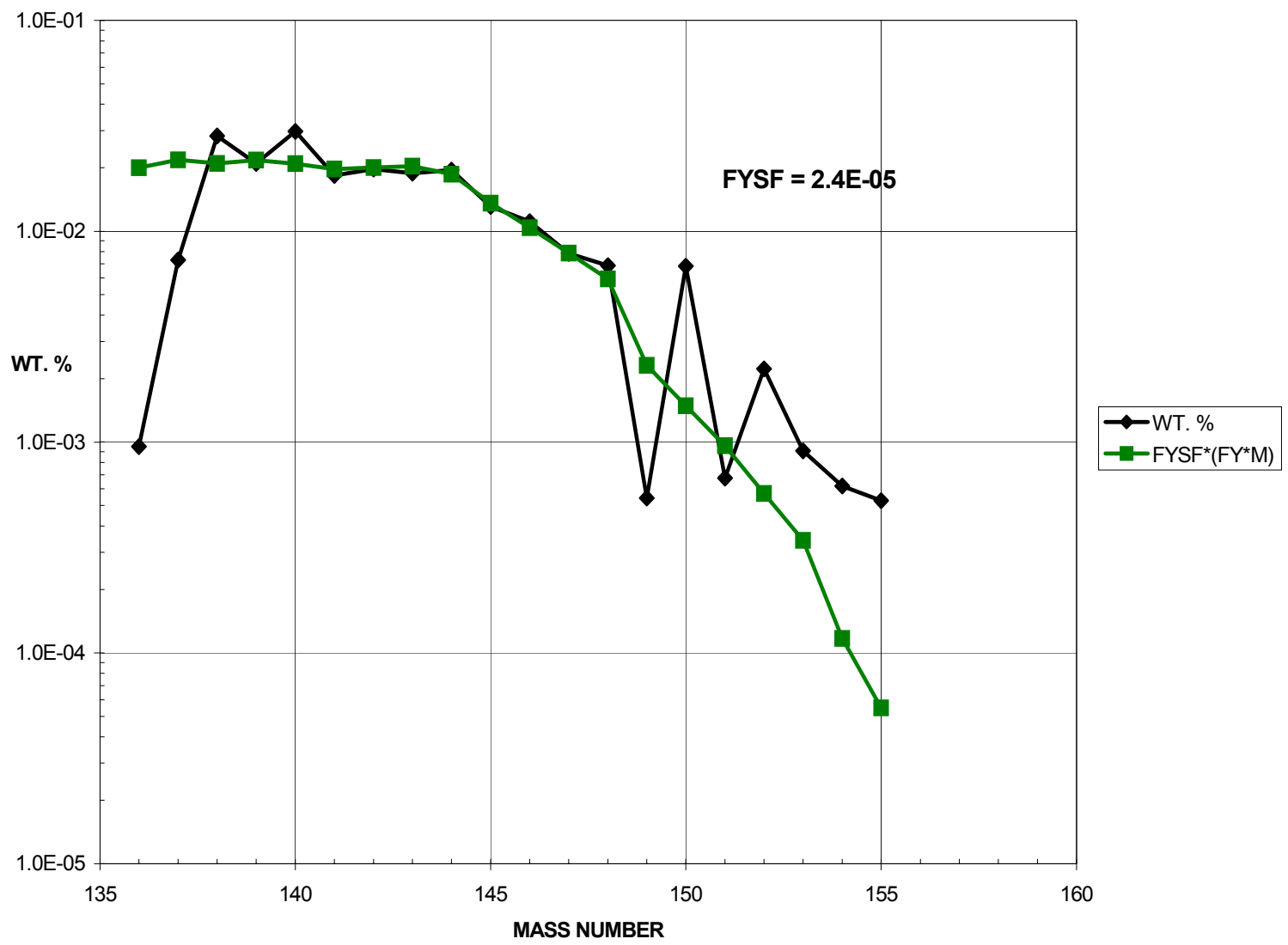

Figure 4-2 Measured and Predicted Concentrations for High Mass Fissions Products in the Tank 40 SB2 Sample (Measured are the solid diamonds and predicted are the solid squares.)

The measured concentrations are the diamonds and the predicted values are the squares. Note that the results for the eleven isotopes in Table 4-1 fall on the line as expected. Why some of the measured results are above and below is explained as follows. The isotopes at masses 149 and 151 are Sm-149 and Sm-151. Both have high neutron absorption cross sections and are transmuted in the reactors giving higher values than predicted for Sm-150 and Sm-152. The isotopes at masses $\mathrm{Ba}-138$ and $\mathrm{Ce}-140$ These are fission products as well as the major isotopes of natural $\mathrm{Ba}$ and $\mathrm{Ce}$, respectively. Their measured concentrations are above the predicted 
concentrations indicating that apparently some natural $\mathrm{Ba}$ and $\mathrm{Ce}$ was in this sample. The U-235 fission product at mass 136 is stable Xe-136. This inert gas xenon is lost in the processing steps at SRS; thus the concentration measured at mass at 136 is well below the predicted concentration. What was detected at this mass 136 could have been natural Ba-136 which is $\sim 8 \%$ of the natural $\mathrm{Ba}$ and or an Xe-136 impurity in the argon plasma The isotopes at mass 137 are primarily radioactive Cs-137 and its decay product Ba-137. The concentration is below that predicted because Cs-137 is soluble in caustic and is in the salt tanks. At masses 153 and higher, oxides of the rare earth elements created in the Ar plasma of the instrument cause an interference.

Figure 4-3 shows the measured concentrations and predicted concentrations of the high mass fission products detected in the Tank 7 sample by the ICP-MS measurements.

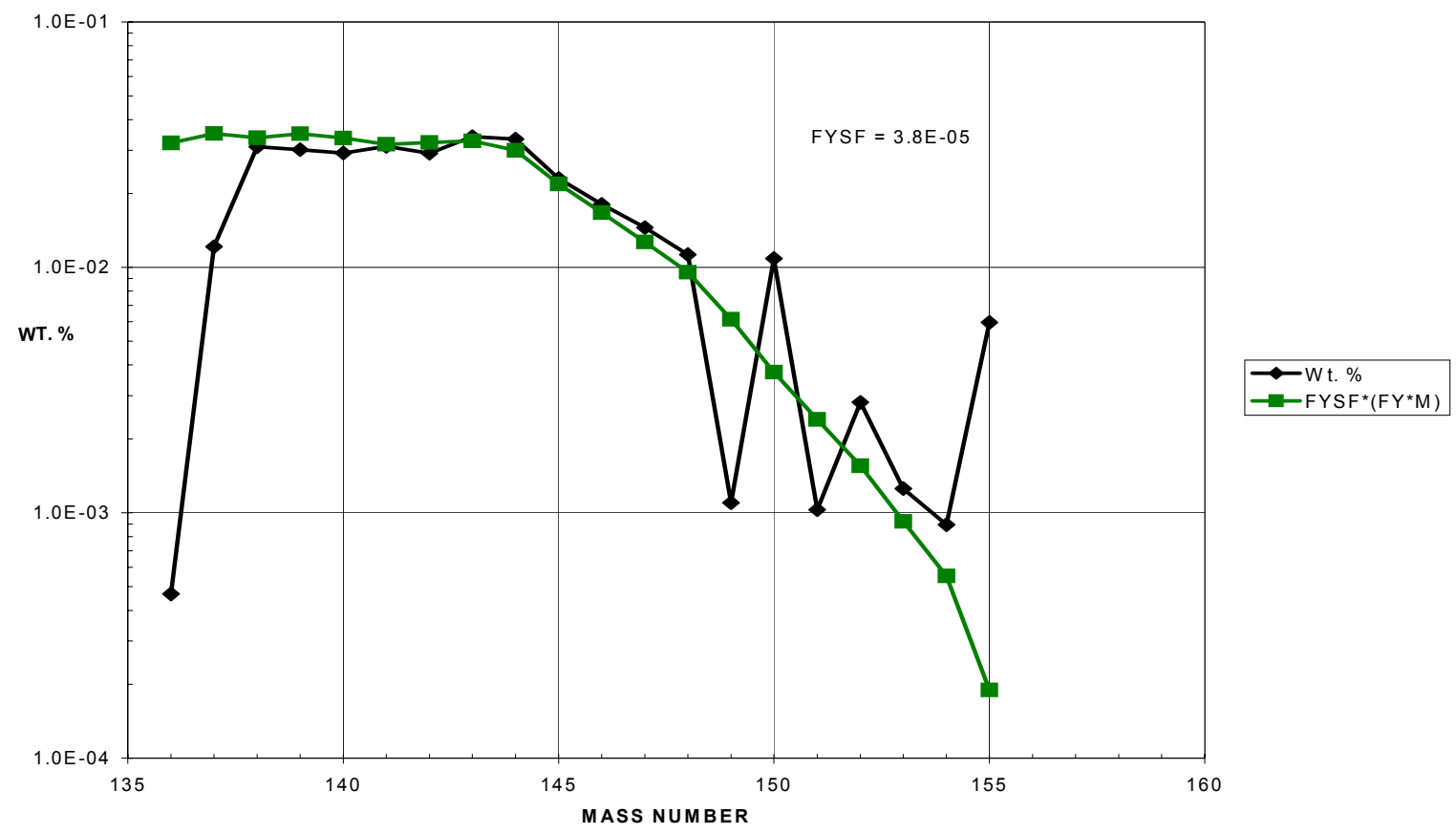

Figure 4-3 Measured and Predicted Concentrations for High Mass Fission Products in the Tank 40 Sludge Bathe Two Sample (Measured are the solid diamonds and predicted are the solid squares.)

The results for the high mass fission products have similar patterns for both the SB2 and the Tank 7 samples. A noteworthy difference is that for the Tank 7 sample the concentrations for Ba-138 and Ce-140 are nearly equal to their predicted concentrations indicating that significant amounts of natural $\mathrm{Ba}$ and $\mathrm{Ce}$ were not present in these samples. 


\subsubsection{Measured and Predicted Concentrations of Low Mass Fission Products in Sludge} Batch Two and a Tank 7 Sample

Figure 4-4 and Figure 4-5 show the results for the low mass fission products in the SB2 and the Tank 7 samples.

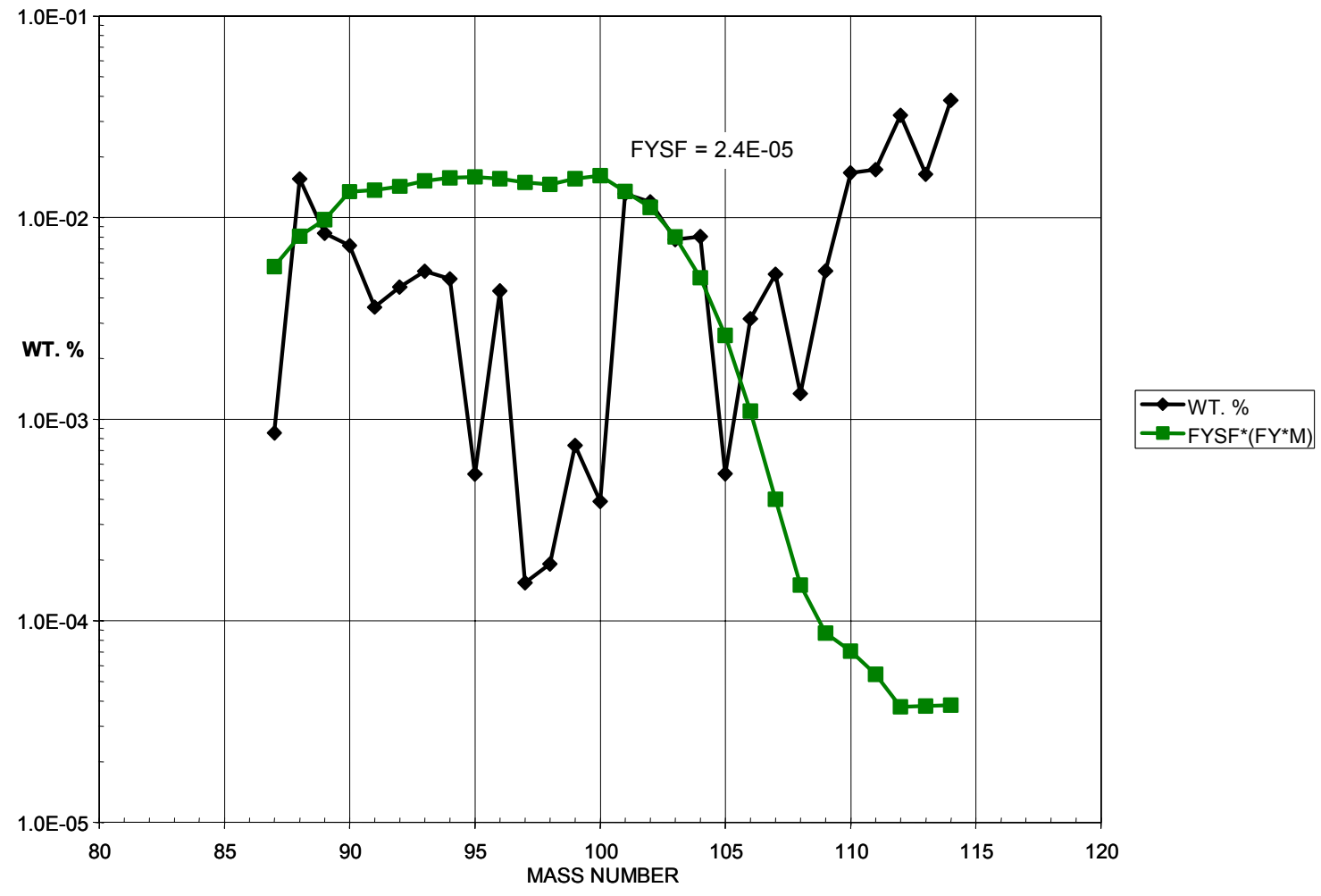

Figure 4-4 Measured and Predicted Concentrations for High Mass Fission Products in the Tank 40 Sludge Batch Two Sample

(Measured are the solid diamonds and predicted are the solid squares.) 


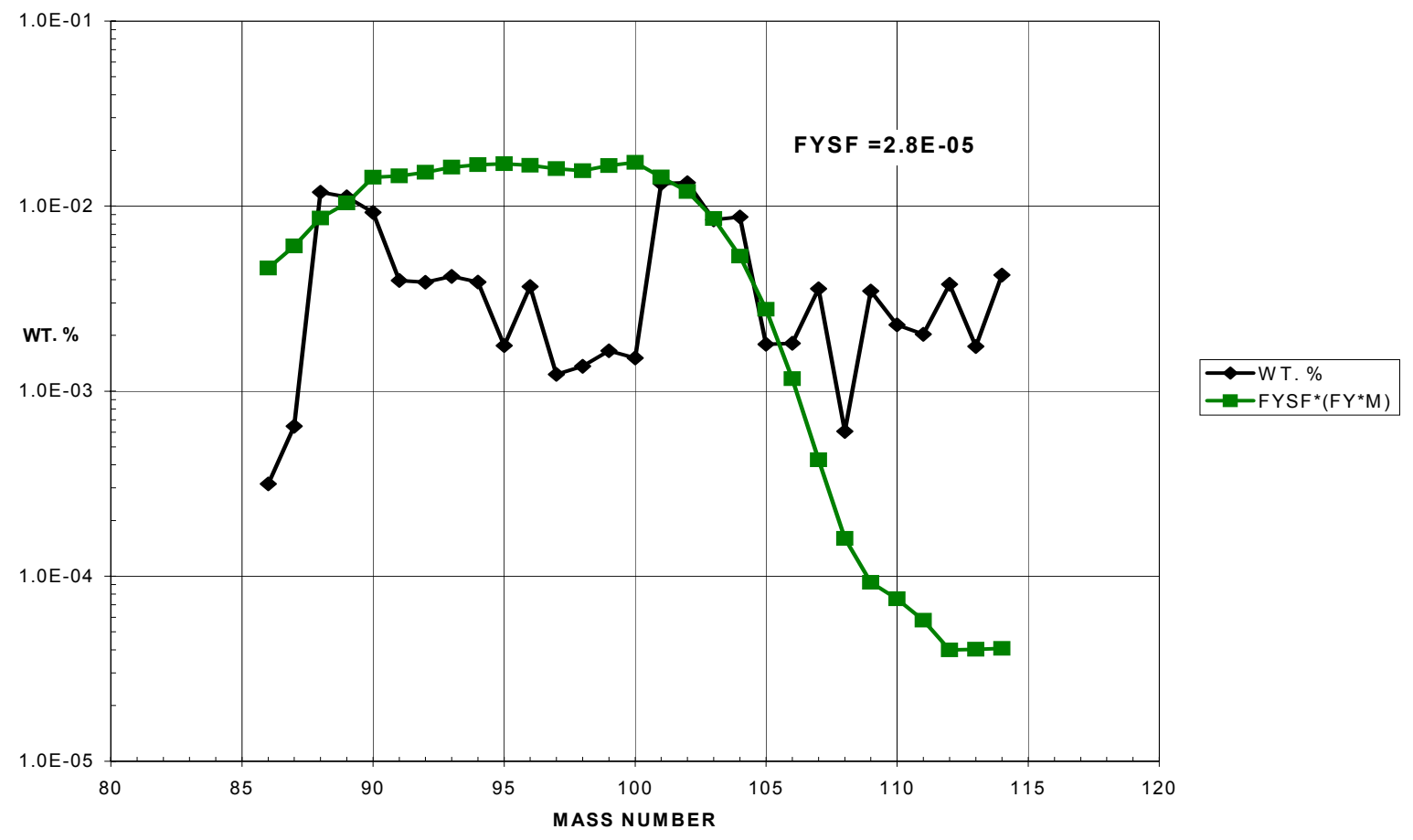

Figure 4-5 Measured and Predicted Concentrations for Low Mass Fission Products in the Tank 7 Sludge Sample (Measured are the solid diamonds and predicted are the solid squares.)

Note that the results for Ru-101, Ru-102, and Rh-103 fall directly on the line as expected. The measured concentrations for Tc-99 and Pd-105 along with several other isotopes are below their predicted concentrations. The isotope at mass 86 is the noble gas $\mathrm{Kr}-86$ which is lost during processing. The detected isotope at 86 is probably $\mathrm{Sr}-86$ that has a natural abundance of $9.9 \%$. Note that the concentration at mass 88 in both Figures is above the predicted. This isotope at mass 88 is $\mathrm{Sr}-88$. This isotope is stable and is both a fission product and an isotope in natural $\mathrm{Sr}-$ 88. Apparently some natural $\mathrm{Sr}$ gets into the waste as a chemical impurity in some chemical that was used in the separations processes at SRS. The isotope at mass 87 is Rb-87 which is soluble in caustic and thus probably primarily in salt tanks. The other isotopes whose concentrations are below the predicted concentrations are those of $\mathrm{Zr}$ and Mo. Zirconium is at masses 91-94 and 96 and Mo isotopes are at masses 95, 97, 98, and 98. Zirconium is insoluble in caustic; thus the reason of its concentration being lower than predicted is not immediately apparent; however it is low in both the SB2 and the Tank 7 sample. The Mo isotopes are low because Mo can form the molybdate anion that is soluble in caustic. The isotopes at mass 107 to mass 114 are isotopes of natural $\mathrm{Ag}$ and $\mathrm{Cd}$ that were in the sludge. Silver was used until the early in 1970 to scavenge radioactive iodine when dissolving the fuels or targets and $\mathrm{Cd}$ was used as to adjust the spectrum of neutron energies in certain charges in the reactors. 


\subsubsection{Calculation of the Fraction of Tc-99 and Pd-105 Removed from a Sample of Sludge Batch Two and a Sample of Tank 7}

It is now possible to calculate the fractions of Tc-99 and Pd-105 that are not in the sludge tanks and are probably in the salt tanks. Results for the two samples discussed above are in Table 4-2 and Table 4-3. Table 4-4 presents results for SB1B.

Table 4-2 Fraction of Tc-99 and Pd-105 Removed from Tank 40 Sludge Batch 2 Slurry by SRS Tank Farm Waste Management Process

\begin{tabular}{||c|c|c|c|c||}
\hline \hline ISOTOPE & $\begin{array}{c}\text { FISSION } \\
\text { YIELD } \\
\text { (PERCENT) }\end{array}$ & $\begin{array}{c}\text { MEAS. CONC. } \\
\text { (WT\% IN DRIED } \\
\text { SLURRY) }\end{array}$ & $\begin{array}{c}\text { PRED. CONC. (a) } \\
\text { (WT\% IN DRIED } \\
\text { SLURRY) }\end{array}$ & $\begin{array}{c}\text { PERCENT } \\
\text { REMOVED(b) }\end{array}$ \\
\hline Tc-99 & 6.10 & $7.4 \mathrm{E}-04$ & $1.4 \mathrm{E}-02$ & $95 \%$ \\
\hline Pd-105 & 0.96 & $5.4 \mathrm{E}-04$ & $2.4 \mathrm{E}-03$ & $78 \%$ \\
\hline
\end{tabular}

(a) Calculated by multiplying the FYSY, 2.6E-05 wt\%/(FY.Mass), times the product of the fission yield times the atomic mass.

(b) Calculated from the equation 1-(Meas. Conc./Pred. Conc.).

Table 4-3 Fraction of Tc-99 and Pd-105 Removed from Tank 7 Slurry by SRS Tank Farm Waste Management Processes

\begin{tabular}{||c|c|c|c|c||}
\hline \hline ISOTOPE & $\begin{array}{c}\text { FISSION } \\
\text { YIELD } \\
\text { (PERCENT) }\end{array}$ & $\begin{array}{c}\text { MEAS. CONC. } \\
\text { (WT\% IN DRIED } \\
\text { SLURRY) }\end{array}$ & $\begin{array}{c}\text { PRED. CONC. (a) } \\
\text { (WT\% IN DRIED } \\
\text { SLURRY) }\end{array}$ & $\begin{array}{c}\text { PERCENT } \\
\text { REMOVED(b) }\end{array}$ \\
\hline Tc-99 & 6.10 & $1.7 \mathrm{E}-03$ & $1.7 \mathrm{E}-02$ & $90 \%$ \\
\hline Pd-105 & 0.96 & $1.8 \mathrm{E}-03$ & $2.8 \mathrm{E}-03$ & $36 \%$ \\
\hline
\end{tabular}

(a) Calculated by multiplying the FYSY, 2.6E-05 wt\%/(FY.Mass), times the product of the fission yield times the atomic mass.

(b) Calculated from the equation 1-(Meas. Conc./Pred. Conc.).

In addition to SB2 and Tank 7, sufficient information has been obtained from the characterization of Sludge Batch 1B (SB1B) to calculate the fractions of Tc-99 and Pd-105 that had been removed from this sludge batch by SRS HLW operations.[7] This sludge slurry was processed in the DWPF using Tank 51 as the feed tank. For SB1B, the plots of measured versus predicted concentrations of the fission products presented in Reference 7, closely resembled the plots presented in this report for SB2 and Tank 7. This included the measured concentrations of the $\mathrm{Zr}$ isotopes being lower than the predicted. 
Table 4-4 Fraction of Tc-99 and Pd-105 Removed from a Tank 51 Slurry Sample of Sludge Batch 1B by SRS Tank Farm Waste Management Process

\begin{tabular}{||c|c|c|c|c||}
\hline \hline ISOTOPE & $\begin{array}{c}\text { FISSION } \\
\text { YIELD } \\
\text { (PERCENT) }\end{array}$ & $\begin{array}{c}\text { MEAS. CONC. } \\
\text { (WT\% IN DRIED } \\
\text { SLURRY) }\end{array}$ & $\begin{array}{c}\text { PRED. CONC. (a) } \\
\text { (WT\% IN DRIED } \\
\text { SLURRY) }\end{array}$ & $\begin{array}{c}\text { PERCENT } \\
\text { REMOVED(b) }\end{array}$ \\
\hline Tc-99 & 6.10 & $1.1 \mathrm{E}-03$ & $1.0 \mathrm{E}-02$ & $89 \%$ \\
\hline Pd-105 & 0.96 & $6.7 \mathrm{E}-04$ & $1.7 \mathrm{E}-03$ & $60 \%$ \\
\hline
\end{tabular}

(a) Calculated by multiplying the FYSY, (1.7E-05 wt\%/(FY.Mass)) times the product of the fission yield times the atomic mass.

(b) Calculated from the equation 1-(Meas. Conc./Pred. Conc.).

In all three sludge slurry samples, the results indicate that 90 to $95 \%$ of the Tc-99 had been removed from these sludge slurry samples by the HLW processes. Apparently it is removed from a sludge slurry by a combination of low fraction of Tc-99precipited and subsequent removal by decantation and washing in the SRS Tank Farm. This results in the bulk of the Tc-99 residing in the salt tanks. This fraction is considerably larger than the fraction of $57 \%$ estimated in 1984[2] and that measured in the stimulant waste (see Section 2.3).

The fraction of Pd-105 that has been removed from the sludge slurries is not as large as that for Tc-99. Also the fraction of Pd-105 removed from the Tank 7 slurry was lower than the fractions removed from the slurries in SB2 and SB1B (36\% compared to 48 and 60\%). The slurries in these latter two tanks had been washed more than that in Tank 7. The slurries in SB2 and SB1B had been washed in preparation for processing them in the DWPF. The slurry in Tank 7 had only been washed by the movement of sludge and salt supernates through Tank 7 during routine operations in the SRS Tank Farm. Perhaps the additional washing of SB2 and SB1B removed more Pd-105.

\subsection{FRACTION OF SOLUBLE AND INSOLUBLE Tc-99 AND Pd-105 IN A WASHED SLUDGE SLURRY}

The fraction of an element that is soluble in a sludge slurry can be determined by comparing the concentration of that element in the supernate of the slurry and in the total dried solids of the slurry. For example it has been found that essentially $100 \%$ of the sulfur in a sludge slurry is soluble in the slurry supernates as the sulfate anion.[16] An equation has been derived that gives the weight fraction of an element in the total dried solids or a slurry calculated by a measurement of the molarity of that element in the supernate of the slurry. This equation is derived in Reference [16].

$$
W_{i}=\frac{M_{i} \cdot M W_{i}}{W_{t s} \cdot D_{\text {sup }}} \cdot \frac{1-W_{t s}}{1-W_{d s}}
$$

where,

$\mathrm{W}_{\mathrm{i}}$ is the calculated weight fraction of element $\mathrm{i}$ in the total solids ( $\mathrm{g}$ of $\mathrm{i} / \mathrm{g}$ of total solids) 
$M_{i}$ is the molarity of element $i$ in the supernate $(\mathrm{mol} / \mathrm{L})$

$\mathrm{MW}_{\mathrm{i}}$ is the atomic weight of element $\mathrm{i}(\mathrm{g} / \mathrm{mole})$

$\mathrm{W}_{\mathrm{ts}}$ is the weight fraction total solids in the slurry (g of total solids/g of slurry)

$\mathrm{W}_{\mathrm{ds}}$ is the weight fraction dissolved solids in the supernate ( $\mathrm{g}$ of dissolved solids/g of supernate)

$\mathrm{D}_{\text {sup }}$ is the density of the supernate $(\mathrm{g} / \mathrm{L})$.

The fraction of the element that is soluble can then be calculated by dividing the result of Equation 1 for that element by the measured weight fraction of that element in the total dried solids of the slurry.

All of the quantities in the above equation are experimentally measured values. We measured the concentrations of Tc-99 and Pd -105 in triplicate samples of the supernate for the slurry sample from SB1B. The value for Tc-99 is reported in Reference [16] and we measured the concentration of Pd-105 as part of this study. All the other have been measured and are reported in Reference [16]. Results are presented in Table 4-5.

\section{Table 4-5 Measured Quantities in Washed SB1B Necessary to Calculate Weight Fraction of Tc-99 and Pd-105 in the Total Dried Solids Based on the Tc-99 and Pd-105 in the Supernate of the Slurry. (a)}

\begin{tabular}{||c|c|c||}
\hline & RESULT & UNITS \\
\hline $\begin{array}{c}\text { Concentration of Tc-99 in } \\
\text { the supernate }\end{array}$ & $2.7 \mathrm{E}-06$ & Moles per liter of supernate \\
\hline $\begin{array}{c}\text { Concentration of Pd-105 in } \\
\text { the supernate }\end{array}$ & $3.5 \mathrm{E}-06$ & Moles per liter of supernate \\
\hline $\begin{array}{c}\text { Fraction of total solids in } \\
\text { the dried slurry }\end{array}$ & 0.188 & $\begin{array}{c}\text { Grams of total dried solids } \\
\text { per gram slurry }\end{array}$ \\
\hline $\begin{array}{c}\text { Fraction of dissolved solids } \\
\text { in the supernate }\end{array}$ & 0.0263 & $\begin{array}{c}\text { Grams of dissolved solids } \\
\text { per gram of supernate }\end{array}$ \\
\hline Density of the supernate & 0.00103 & Grams per liter of supernate \\
\hline
\end{tabular}

(a) See Reference [16] for details.

The weight fraction of Tc-99 in the total dried solids of the SB1B slurry calculated by Equation 1 in 1.2E-06. The measured weight fraction in the total dried solids was 1.1E-05.[7] Based on the above calculation, the fraction of Tc-99 soluble in the supernate is $1.2 \mathrm{E}-06 / 1.1 \mathrm{E}-05$ or only $11 \%$. The remainder of the Tc-99 (89\%) is in the sludge solids probably as TcO2. This high fraction of insoluble is not unexpected since most of the soluble Tc-99 had already been removed by SRS HLW processing operations. For Pd-105, the calculated weight fraction based on that measured in the supernate was 1.6E-06. The measured fraction in the total dried solids was 6.7E-06.[7] On this basis, $24 \%$ of the $\mathrm{Pd}-105$ is soluble and $76 \%$ insoluble. The $\mathrm{Pd}$ in the sludge solids is 
probably in the form of an hydrous oxide. In caustic solutions, Pd can form the soluble $\mathrm{Pd}(\mathrm{OH})_{4}{ }^{2-}$ anion. These results raise the question of how much of these isotopes could be removed from the sludge solids by extended washing of the sludge solids with alkaline wash solutions.

\subsection{FRACTION OF Tc-99, Pd-105, AND OTHER SELECED ELEMENTS THAT COULD BE REMOVED FROM AN UNWASHED SLURRY BY EXTENDED WASHING}

A test was performed in the Shielded Cells to determine what fraction of Tc-99 and Pd-105 could be removed from an unwashed sludge slurry by extensive washing of the solids with inhibited water (IW). For the IW we used a solution of $0.010 \mathrm{M} \mathrm{NaOH}$ and $0.010 \mathrm{M} \mathrm{NaNO}_{2}$ that is used in the SRS Tank Farm to wash sludges. A solution of this type is used to inhibit corrosion of the mild steel of the tank during washing. For this test we put approximately 30 grams of a slurry from Tank 40 (SB2) that had not been washed on a filter and then filtered the slurry. Based on the initial characterization of the unwashed slurry, approximately 7 grams of sludge solids were left on the filter. These solids were then washed on that same filter four times with $40 \mathrm{~mL}$ of IW and then twice with $100 \mathrm{ml}$ of IW. After each addition of wash solution to the filter, the solids and wash solution were mixed for $\sim$ five minutes to wash the solids. We then separated the wash solution from the solids by filtration. After the test, aliquots of the individual wash solutions were removed from the shielded cells and sent to ADS for analysis. They were analyzed for the major elements in the SB2 sample by ICP-ES, for U-235 fission products by ICP-MS and for Cs137 by gamma counting. The $\mathrm{u}-238$ concentration was also determined by ICP-MS analysis. Duplicate samples of the unwashed dried slurry and of the final washed, dried solids were dissolved by hot aqua regia to determine the compositions of the dried solids. 
Concentrations of Tc-99 and Pd-105 in the wash solutions along with concentration of other selected elements are plotted in Figure 4-6.

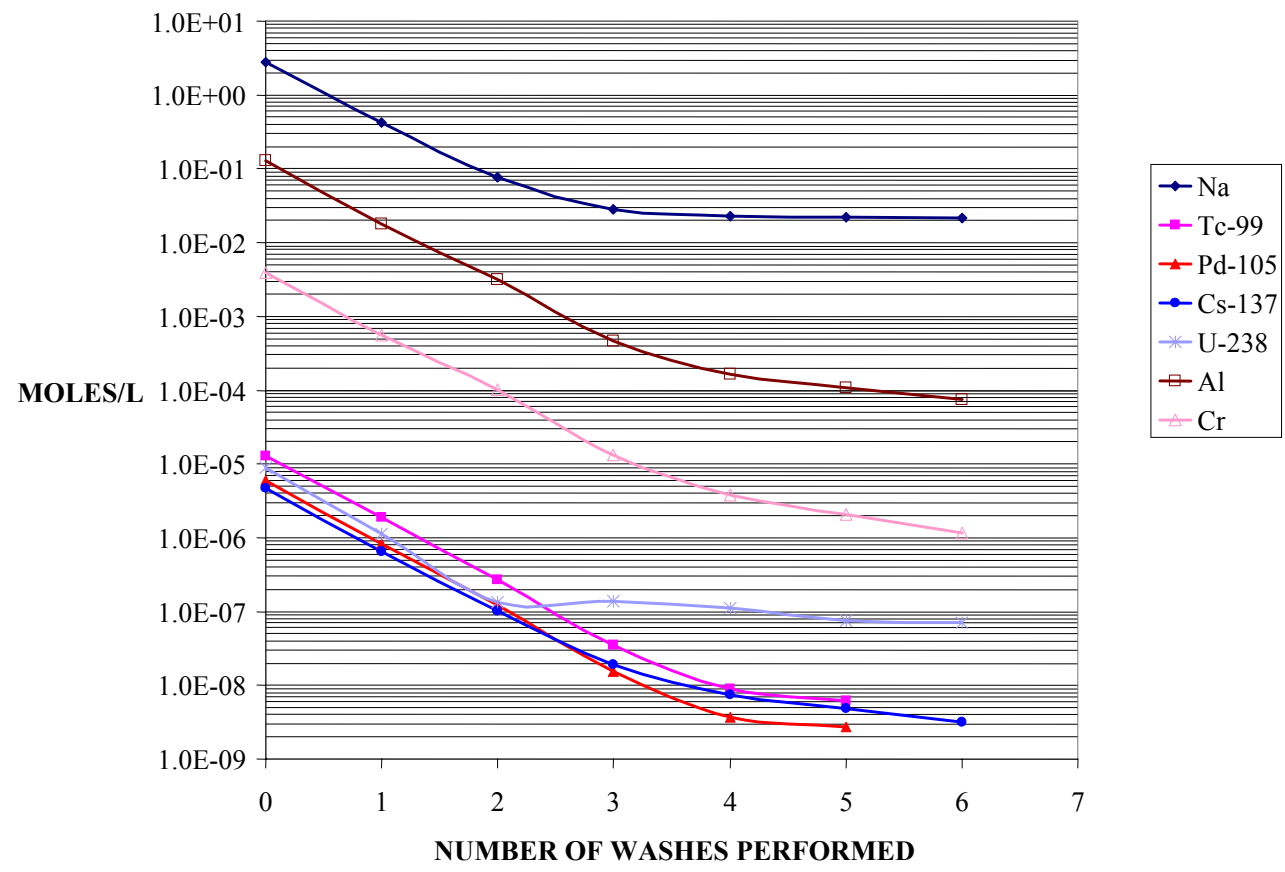

\section{Figure 4-6 Molar Concentrations in the Supernate and Wash Solutions of the Extended Washing of the Solids in a Sample of SB2 from Tank 40. (Washes 1-4 were with $40 \mathrm{~mL}$ IW solution and 5-6 were with 100mLof IW solution.)}

The concentration of $\mathrm{Na}$ in the wash solutions decreased from $3.8 \mathrm{M}$ to a constant value of $0.02 \mathrm{M}$ which is its concentration in the IW solution. The concentrations of the other elements including Tc-99, Pd-105, and Cs-137 initially followed the same trend; however it appears that their concentrations may have continued to decrease slightly rather than reaching a constant value. However in these solutions the concentrations of these isotopes were very low. For example, in the final wash solution, the concentrations of Tc-99 and Pd-105 were too low to be detected by the ICP-MS; however, Cs-137 could till be detected by gamma counting of the wash solutions.

Note that the U-238 concentration no longer decreases after wash 2 indicating that after wash 2 the U-238 is dissolving from the solids into the wash solution. This behavior has been observed in dilutions of a simulated HLW slurry containing waste solids of $\mathrm{Fe}, \mathrm{Al}, \mathrm{Mn}, \mathrm{Ni}$, and $\mathrm{U}$ that were precipitated from an acidic simulated HLW solution.[17] At Na concentrations below $0.12 \mathrm{M}$ the $\mathrm{U}$ began to dissolve from the simulated HLW solids in those tests. This dissolution behavior has also been observed in a washing study using simulated Tank 7 sludge doped with solid $\mathrm{Na}_{2} \mathrm{C}_{2} \mathrm{O}_{4}$. [18] In that study the $\mathrm{Na}_{2} \mathrm{C}_{2} \mathrm{O}_{4}$. begin to dissolved from the solids after the $\mathrm{Na}$ concentration in the supernate decreased from $\sim 4 \mathrm{M}$ to $2 \mathrm{M}$. 
For the first three washes, the concentrations of all the elements in the wash solutions except U238 decrease linearly in Figure 4-6 indicating that a constant fraction of each element is being removed by each wash solution. Going from wash 3 to wash 4 the slope decreases for each indicating a slightly lower fraction being removed in the fourth wash. This trend is more dramatically presented in tabular form.

Table 4-6 gives the measured values for the concentrations in initial supernate and the first four wash solutions. The last column of the table gives the concentration of $\mathrm{Na}$ that came from washing the sludge solids and not from the IW. This concentration was calculated by subtracting $0.020 \mathrm{M}$ (the concentration of $\mathrm{Na}$ in the IW) from the measured concentrations of $\mathrm{Na}$ in the wash solution. Table 4-7 presents the fractional decreases calculated for each of the wash.

Table 4-6 Molar Concentrations in the Initial Supernate and the First Four Washed of the SB2 Sludge Slurry (a)

\begin{tabular}{||c|c|c|c|c|c|c|c|c||}
\hline \hline SOLN. & Na & Tc-99 & Pd-105 & Cs-137 & Al & Cr & U-238 & $\begin{array}{c}\text { CORR } \\
\text { Na (b) }\end{array}$ \\
\hline $\begin{array}{c}\text { Initial } \\
\text { Supernate }\end{array}$ & $2.8 \mathrm{E}+00$ & $1.3 \mathrm{E}-05$ & $5.9 \mathrm{E}-06$ & $4.6 \mathrm{E}-06$ & $1.3 \mathrm{E}-01$ & $3.9 \mathrm{E}-0$ & $3.9 \mathrm{E}-08$ & $2.8 \mathrm{E}+00$ \\
\hline 1st Wash & $4.2 \mathrm{E}-01$ & $1.9 \mathrm{E}-06$ & $8.3 \mathrm{E}-07$ & $6.6 \mathrm{E}-07$ & $1.8 \mathrm{E}-02$ & $5.6 \mathrm{E}-04$ & $1.1 \mathrm{E}-06$ & $4.0 \mathrm{E}-01$ \\
\hline 2ndWash & $7.7 \mathrm{E}-02$ & $2.7 \mathrm{E}-07$ & $1.2 \mathrm{E}-07$ & $1.0 \mathrm{E}-07$ & $3.2 \mathrm{E}-03$ & $1.0 \mathrm{E}-04$ & $1.3 \mathrm{E}-07$ & $5.7 \mathrm{E}-02$ \\
\hline 3rd Wash & $2.8 \mathrm{E}-02$ & $3.5 \mathrm{E}-08$ & $1.5 \mathrm{E}-08$ & $1.9 \mathrm{E}-08$ & $4.6 \mathrm{E}-04$ & $1.3 \mathrm{E}-05$ & $1.4 \mathrm{E}-07$ & $8.1 \mathrm{E}-03$ \\
\hline 4th Wash & $2.3 \mathrm{E}-02$ & $8.9 \mathrm{E}-09$ & $3.7 \mathrm{E}-09$ & $7.4 \mathrm{E}-09$ & $1.6 \mathrm{E}-04$ & $3.8 \mathrm{E}-06$ & $1.1 \mathrm{E}-07$ & $2.6 \mathrm{E}-03$ \\
\hline
\end{tabular}

(a) Each wash was with $40 \mathrm{~mL}$ of IW (0.01M NaOH and 0.01M NaNO2).

(b) $\mathrm{Na}$ concentration corrected for $\mathrm{Na}$ from the IW.

Table 4-7 Fractional Deceases in Each of the First Four Washes of the SB2 Sludge Slurry (a)

\begin{tabular}{||c|c|c|c|c|c|c|c||}
\hline \hline & $\begin{array}{c}\text { CORR } \\
\text { Na (b) }\end{array}$ & Tc-99 & Pd-105 & Cs-137 & Al & Cr & U-238 \\
\hline 1st Wash & 0.86 & 0.85 & 0.86 & 0.86 & 0.86 & 0.86 & 0.88 \\
\hline 2nd Wash & 0.86 & 0.86 & 0.85 & 0.85 & 0.82 & 0.82 & 0.88 \\
\hline 3rd Wash & 0.86 & 0.87 & 0.88 & 0.81 & 0.85 & 0.87 & -0.04 \\
\hline 4th Wash & 0.67 & 0.75 & 0.76 & 0.61 & 0.65 & $0 . .71$ & 0.19 \\
\hline
\end{tabular}

(a) Each wash was with $40 \mathrm{~mL}$ of IW $(0.01 \mathrm{M} \mathrm{NaOH}$ and $0.01 \mathrm{M} \mathrm{NaNO} 2)$.

(b) $\mathrm{Na}$ concentration corrected for $\mathrm{Na}$ from the IW.

The fractional decreases in each wash were calculated by dividing the difference between the concentrations in the two successive wash solution by the concentration in the previous solution. Note that for the first three washes these fractional decreases for all of the four elements are equal. This confirms that the main mechanism for removing these elements from the sludge solids is dilution of each element in the solution adhering to the solids after each wash by the added wash solution. One is simply removing the soluble elements in the solution by dilution rather than the dissolution of a slightly soluble compound of that species. The equation for this type of washing mechanism is given below.[19] 


$$
C_{n}=\left(\frac{v}{V+v}\right)^{n} \cdot C_{o} \quad 4
$$

Where

$C_{n}$ is the concentration in the nth wash

$C_{0}$ is the initial concentration

$V$ is the volume of the wash solution (in this case $40 \mathrm{~mL}$ )

$v$ is volume of supernate or wash solution that remains adhering to the solids after each wash.

Taking the log of both sides results in the following equation.

$$
\log C_{n}=n \log \left(\frac{v}{V+v}\right)+\log C_{o} \quad 5
$$

Since $40 \mathrm{~mL}$ were used in each wash and the volume adhering to the solids should have essentially the same the same after each $40 \mathrm{~mL}$ wash, the factor $\log (v /(v+V))$ is a constant. Thus a plot of $\log C_{n}$ versus $n$ for each $40 \mathrm{~mL}$ wash should be linear. As shown in Figure 4-6 this is indeed true for all the elements except U-238. At low Na Concentrations it appears that some U238 is being dissolved out of the sludge solids.

The total fraction of each element removed by the extended washing can be calculated by comparing the composition of the unwashed total solids of the dried unwashed slurry with the composition of dried washed solids. Table 4-8 presents these concentrations for several along with ratios of their respective concentrations.

Table 4-8 Concentration of Elements Measured in the Unwashed and Totally Washed Solids of a Tank 40 SB2 Slurry

\begin{tabular}{||c|c|c|c||}
\hline ELEMENT & $\begin{array}{c}\text { WEIGHT \% IN } \\
\text { UNWASHED } \\
\text { SOLIDS }\end{array}$ & $\begin{array}{c}\text { WEIGHT \% IN } \\
\text { WASHED } \\
\text { SOLIDS }\end{array}$ & $\begin{array}{c}\text { RATIO OF } \\
\text { WASH' TO } \\
\text { UNWASH }\end{array}$ \\
\hline $\mathrm{Al}$ & 4.2 & 6.8 & 1.6 \\
\hline $\mathrm{Ca}$ & 1.2 & 2.9 & 2.4 \\
\hline $\mathrm{Cd}$ & 0.074 & 0.17 & 2.4 \\
\hline $\mathrm{Cr}$ & 0.15 & 0.18 & 1.2 \\
\hline $\mathrm{Fe}$ & 13. & 30. & 2.3 \\
\hline $\mathrm{Mg}$ & 0.98 & 2.4 & 2.4 \\
\hline $\mathrm{Mn}$ & 1.8 & 4.0 & 2.2 \\
\hline $\mathrm{Na}$ & 21. & 2.8 & 0.13 \\
\hline $\mathrm{Tc}-99$ & $8.0 \mathrm{E}-04$ & $1.1 \mathrm{E}-03$ & 1.4 \\
\hline $\mathrm{Pd}-105$ & $5.1 \mathrm{E}-04$ & $6.3 \mathrm{E}-04$ & 1.2 \\
\hline $\mathrm{Cs}-137$ & $3.4 \mathrm{E}-04$ & $2.7 \mathrm{E}-04$ & 0.79 \\
\hline $\mathrm{U}-238$ & 3.7 & 7.9 & 2.1 \\
\hline
\end{tabular}


Note that for the elements that are insoluble in caustic $(\mathrm{Ca}, \mathrm{Cd}, \mathrm{Fe}, \mathrm{Mg}$, and $\mathrm{Mn})$ this ratio has a constant value of 2.3 with a \%RSD of only $3 \%$. For those elements that have some solubility in the sludge slurry supernates, the ratio is lower than 2.3. For $\mathrm{Na}$ it is very low because clearly most of the Na was in the unwashed slurry is in the supernate. This is also true with Cs-137 which has a high solubility in caustic.

The fractions of elements removed by the extensive washing were then calculated by comparing their measured concentrations in the washed solids with the concentrations predicted by assuming that they were completely insoluble in IW and none had been washed out. Results of this comparison are shown in Table 4-9.

Table 4-9 Fractions of Elements Removed from a Tank 40 SB2 Slurry by Supernate Removal Followed by Extended Washing of the Solids

\begin{tabular}{||c|c|c|c|c||}
\hline \hline ELEMENT & $\begin{array}{c}\text { WT\% IN } \\
\text { UNWASH' } \\
\text { DRIED } \\
\text { SOLIDS(a) }\end{array}$ & $\begin{array}{c}\text { MEASURED } \\
\text { WT\% IN } \\
\text { WASHED } \\
\text { SOLIDS }\end{array}$ & $\begin{array}{c}\text { PRED. WT\% IN } \\
\text { WASHED } \\
\text { SOLIDS(b) }\end{array}$ & $\begin{array}{c}\text { PERCENT } \\
\text { REMOVED BY } \\
\text { WASHING (c) }\end{array}$ \\
\hline $\mathrm{Tc}-99$ & $8.0 \mathrm{E}-04$ & $1.1 \mathrm{E}-03$ & $1.9 \mathrm{E}-03$ & 41 \\
\hline $\mathrm{Pd}-105$ & $5.1 \mathrm{E}-04$ & $6.3 \mathrm{E}-04$ & $1.2 \mathrm{E}-03$ & 47 \\
\hline $\mathrm{Al}$ & 4.1 & 6.8 & 9.5 & 29 \\
\hline $\mathrm{Cr}$ & 0.15 & 0.18 & 0.35 & 48 \\
\hline $\mathrm{U}-238$ & 3.7 & 7.9 & 8.6 & 8.1 \\
\hline $\mathrm{Cs}-137$ & $3.4 \mathrm{E}-04$ & $2.7 \mathrm{E}-04$ & $7.6 \mathrm{E}-04$ & 64 \\
\hline $\mathrm{Na}$ & 21 & 2.8 & 49 & 94 \\
\hline
\end{tabular}

(a) Weight percent in total dried solids of the unwashed slurry. This includes the amount of the element in the sludge supernate and the amount of the element in the solids.

(b) Calculated by multiplying the weight percent in the total dried solids by 2.3 , the ratio of concentrations for elements that are insoluble.

(c) Calculated from the equation $1-(\mathrm{wt} \%$ in washed solids $/$ predicted $\mathrm{wt} \%)$.

For both Tc-99 and Pd-105, 56\% of each element in the unwashed sludge slurry was insoluble in IW and not removed by washing. For Cs-137, 36\% is not removed by the extended washing. In a washing study starting with unwashed sludge slurry from Tank 42 , it was found that $86 \%$ of the Cs-137 was insoluble and not washed out by extended washing with IW.[20] In that study it was also found that $30 \%$ of the $\mathrm{Na}$ was insoluble and not washed out. In this study only $6 \%$ of the sodium was insoluble and not washed out with the IW solution. It must be stated that there is no reason for the fractions of insoluble $\mathrm{Na}$ or $\mathrm{Cs}-137$ to be equal in different tanks since the tanks have different amounts of sludge supernates and sludge solids prior to the washing process. Also there cold be a different distribution of solid phases that contain $\mathrm{Na}$ and Cs-137.

The results in this Section clearly show that the main mechanism in removing elements from a sludge slurry during SRS Tank Farm operations is sludge supernate dilution and removal and not dissolution of any insoluble species. This is true even for $U$ where the present study showed some dissolution of $\mathrm{U}$ when the $\mathrm{Na}$ concentrations got below $0.08 \mathrm{M}$. In the Tank Farm however, the $\mathrm{Na}$ concentrations would not get this low because of the necessity of have certain concentrations of $\mathrm{NaNO}_{2}$ and $\mathrm{NaOH}$ present ion the slurry to prevent corrosion of the tank itself. 


\subsection{POSSIBLE LOSSES OF Tc-99 IN DWPF PROCESSING}

The final step in the sludge waste processing at SRS is the immobilization of the sludge into a stable borosilicate glass for geologic disposal. This is performed in the DWPF where the sludge slurry is mixed with glass forming frit and pumped into a melter at $1150^{\circ} \mathrm{C}$. Here the water is flashed off and the sludge solids and frit melt into a molten solution.

The primary process where Tc-99 may be lost in the DWPF process is volatilization from the DWPF melter since Tc-99 can form an oxide that has a boiling point of $\sim 311^{\circ} \mathrm{C}$.[3] For example, in laboratory and large scale melter studies it has been shown that substantial amounts (up to 60\%) of the Tc-99 can be volatized from the molten glass.[21]

During the processing of SB1A (Macrobatch 1) in the DWPF, sufficient information was obtained to determine the fraction of Tc-99 that was lost to the DWPF off gas system and not immobilized in the glass.[22] This determination was made by comparing the amount of Tc-99 in the feed to the DWPF process to the amount measured in three glass samples from the pour stream of the melter during processing. These results have been published in an earlier report.[22] They will be presented here in order to complete the picture of the behavior of Tc-99 in the sludge waste processing. Prior to discussing results of that report, it is helpful to summarize the DWPF process as background information.

A batch of sludge (nominally 1.5 million liters) is prepared in the SRS Tank Farm by combining several sludge slurries from appropriate tanks. The combined slurry is then washed to remove a large portion of the soluble salts in the slurry. Final washing of the batch occurs in either Tank 51 or 40 . Both of these tanks are directly piped to the DWPF as feed tanks. From the DWPF feed tank, smaller batches (nominally 20 thousand liters) of the washed sludge are sent to the DWPF for processing; thus, it usually takes 2 to 3 years to process the entire large batch. Over this period the composition of the smaller batches remain constant due to efficient mixing of the slurry in the DWPF feed tank.[23]

In the DWPF there are pretreatment steps to remove mercury from the slurry and to adjust its rheology. Then a glass forming frit (primarily silica and boric oxide) is added to the slurry. The sludge slurry and frit are thoroughly mixed and then fed to a Joule heated melter at $1150^{\circ} \mathrm{C}$. In the melter, water is evaporated from the slurry and the sludge solids and frit form a molten solution in the melter. Aliquots of this molten solution are fed to stainless steel canisters ( $3 \mathrm{~m}$ tall and $0.6 \mathrm{~m}$ in diameter) where the solution solidifies as a borosilicate glass for final disposal in a geologic repository. Processing of SB1A, which took $\sim 30$ months, produced $\sim 0.9$ million kilograms of HLW glass that was poured into 495 canisters.

During processing of SB1A, glass samples were taken from the pour stream of the melter while three different canisters were being filled. These were canisters 50, 61, and 409 of the campaign. The concentration of Tc-99 was measured in each of these glass samples and compared to the predicted concentration from the composition of the sludge slurry being immobilized. The predicted concentrations were calculated using a waste dilution factor (WDF). The WDF is simply the factor that the concentrations in the feed are diluted by the addition of the glass forming frit. Values for the WDF were calculated based on the concentrations of the four major 
element $\sin$ the waste ( $\mathrm{Fe}, \mathrm{Al}, \mathrm{Ca}$, and $\mathrm{Mn}$ ) and their respective concentrations measured in the glass samples from the three canisters. For each of the three canisters, the average WDF calculated for each of the four elements was a constant with a $\%$ RSD of $7 \%$ or better. The predicted concentration of Tc-99 in a glass sample was then calculated by dividing its concentration in the feed by the appropriate WDF for that glass sample. Results are summarized in Table 4-10.

\section{Table 4-10 Measured and Predicted Tc-99 Concentrations in Glass from DWPF Melter Pour Stream Sampled During Filling of Three Canisters During SB1A Processing (a)}

\begin{tabular}{||c|c|c|c|c||}
\hline & DATE FILLED & $\begin{array}{c}\text { MEASURED } \\
\text { WT.\% }\end{array}$ & $\begin{array}{c}\text { PREDICTED } \\
\text { WT.\% }\end{array}$ & $\begin{array}{c}\text { PERCENT } \\
\text { DIFFERENCE } \\
\text { (b) }\end{array}$ \\
\hline Canister 50 & $9 / 21 / 96$ & $4.3 \mathrm{E}-04$ & $4.5 \mathrm{E}-04(\mathrm{c})$ & 4.4 \\
\hline Canister 61 & $9 / 23 / 96$ & $4.1 \mathrm{E}-04$ & $4.2 \mathrm{E}-04(\mathrm{~d})$ & 2.4 \\
\hline Canister 409 & $6 / 30 / 98$ & $4.7 \mathrm{E}-04$ & $4.5 \mathrm{E}-04(\mathrm{e})$ & -4.4 \\
\hline
\end{tabular}

(a) See Reference 22 for details.

(b) Calculated from ((Pred. Conc.-Meas. Conc.)/Pred. Conc) X 100)

(c) Calculated by dividing the Tc-99 concentration in the DWPF feed by the WDF of 2.8 based on measurements of $\mathrm{Fe}, \mathrm{Al}, \mathrm{Ca}$, and $\mathrm{Mn}$ in the feed and Canister 50 glass.

(d) Calculated by dividing the Tc-99 concentration in the DWPF feed by the WDF of 3.1 based on measurements of $\mathrm{Fe}, \mathrm{Al}, \mathrm{Ca}$, and $\mathrm{Mn}$ in the feed and Canister 61 glass.

(e) Calculated by dividing the Tc-99 concentration in the DWPF feed by the WDF of 2.8 based on measurements of $\mathrm{Fe}, \mathrm{Al}, \mathrm{Ca}$, and $\mathrm{Mn}$ in the feed and Canister 409 glass. The negative value indicates that the measured concentration was larger (albeit by a small amount) than the predicted.

The results in the last column of Table 4-10 indicate that only a small fraction, if any, of the Tc99 volatilizes from the melter to the DWPF off gas system. For Canister 409 the measured concentration was greater than the predicted but it was shown that this is due to the analytical uncertainty of the data.[22] However, evidence for the presence of Tc-99 in the off gas deposits was obtained by analyzing three radioactive deposits from the off gas system of Melter One at the DWPF.[24] Melter One was used in the DWPF for eight years during the processing of SB1A, SB1B, and part of SB2 before Melter One failed. The three deposits were obtained in November 2002 when Melter One was being replaced by Melter Two. By comparing the ratios of Tc-99 to Fe or Sr-90 in the off gas deposits to their respective ratios in the melter feed, it was determined that there was indeed some volatility of Tc-99 from the melter. (The ratios in the off gas deposits were larger than their respective ratios in the melter feed.) Based on the results in Table 4-10, the amount of Tc-99 that did volatilize was insignificant compared to the total Tc-99 in the waste being processed. 
One reason that Tc-99 does not volatilize from the DWPF melter is that the water in the sludge slurry causes a cold cap to be formed on the melter. During feeding it has been estimated that the melt surface is $95 \%$ covered by the cold cap. In the laboratory and other studies where large losses were encountered[21], no cold cap was present. Also in a small scale melter operated remotely at SRTC, Tc-99 losses were determined to be much higher than in the DWPF melter (31\% compared to the 4\%). [22] Even though this melter was slurry fed, the feed rate was too slow to allow the formation of a cold cap and thus the Tc-99 losses were higher. Another possibility for the lower volatility of the Tc-99 is that the Tc-99 could have been reduced to the +4 state by the formic acid added in one of the DWPF pretreatment steps. The +4 state forms a less volatile oxide than the +7 state.[21]

\subsection{DISSOLUTION OF Tc-99 FROM HLW SLUDGE BY OXALIC ACID FOR TANK CLEANING}

Oxalic acid has been investigated as a possible chemical for cleaning of HLW tanks for permanent closing of a tank. A recent report has summarized the results of a literature survey concerning the use of oxalic acid as a cleaning agent of HLW storage tanks.[25] In that report, data was presented that showed that oxalic acid can dissolve significant amounts of $\mathrm{Mn}, \mathrm{Al}$ and $\mathrm{Fe}$ from the sludge solids. In only one of the references cited were results presented for Tc99.[26] That study used sludges from Hanford Tank 241-C-106 and AY-102. Results for C-106 indicated that at $23^{\circ} \mathrm{C}$ with $\sim 9 \mathrm{wt} . \%$ oxalic acid some Tc-99 could be dissolved. As the ratio of the acid solution to sludge volume ratio increased from 10 to 20 the amount of Tc-99 dissolved increased by $\sim 2 X$. In a kinetic study with AY-102, it was estimated that $91 \%$ of the Tc-99 could be dissolved in 18 days with nominally $10 \mathrm{~mL}$ of $1 \mathrm{M}$ oxalic acid per gram of dry AY-102 sludge.

At SRS, oxalic acid was used in an attempt to remove zeolite from Tank 24[27] and in a full scale cleaning demonstration of Tank 16[28]. Only $5 \%$ of the zeolite was removed from Tank 24. [27] In the Tank 16 demonstration, $\sim 99 \%$ of the waste that was initially in the tank was removed hydraulically by sluicing and pumping operations. The interior surfaces of the tank were then sprayed with a solution of $4 \mathrm{wt} . \%$ oxalic acid to clean them. It was estimated that this removed even more of the waste so that only $\sim 0.1 \%$ of the original waste remained in the tank. Data for several radionuclides was reported but Tc-99 was not measured in that demonstration. 
In this study we did three tests in the SRTC Shielded Cells to determine how much Tc-99 could be dissolved from a HLW sludge by oxalic acid. Tests were done with both the unwashed and the over washed Tank 40 sludge solids discussed in Section 4.3 and with an archived sample of Tank 11 solids. First a test with a simulated sludge was performed to make visual observations and determine the crystalline content of the undissolved solids Upon addition of the acid to the slurry, bubbles were evolved due to the formation of gaseous carbon dioxide being formed from carbonates being dissolved by the acid. Eventually the supernate became greenish yellow. This color change is shown in Figure 4-7 for the test using simulated sludge.

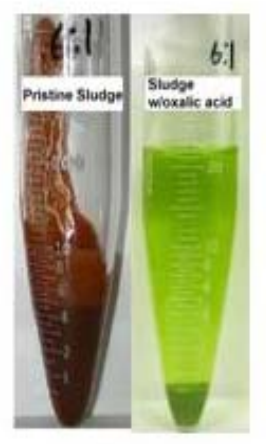

\section{Figure 4-7 Color Changes Observed During Oxalic Acid Digestion of a Caustic Simulated High Level Waste Solution}

In this test we added $18 \mathrm{~mL}$ of $0.9 \mathrm{M}$ oxalic acid to $3 \mathrm{~mL}$ of a simulated HLW sludge slurry. The greenish color is due to the formation of the ferrous oxalate complex ion. The sludge solids changed from a brownish color to a lighter greenish color. It appeared that the volume of the sludge solids decreased. Analysis of the solids by X-ray diffraction for crystalline solids indicated the presence of $\mathrm{SiO}_{2}$, along with $\mathrm{NiC}_{2} \mathrm{O}_{4}$ and $\mathrm{CaC}_{2} \mathrm{O}_{4}$. No crystalline compounds containing $\mathrm{Fe}$ or $\mathrm{Al}$ were detected. Results of the Hanford study using oxalic acid [26] indicated the presence of $\mathrm{MnC}_{2} \mathrm{O}_{4}$ along with $\mathrm{Fe}_{2} \mathrm{O}_{3}, \mathrm{Al}(\mathrm{OH})_{4}$, and $\mathrm{AlO}(\mathrm{OH})$. The presence of $\mathrm{Fe}$ and $\mathrm{Al}$ in the solids suggests that their dissolution was not as complete as the dissolution in this study.

For the tests with the three radioactive HLW sludges, we used nominally 0.25 grams of dried Tank 40 sludge solids and 0.4 grams of dried Tank 11 solids. Then $9 \mathrm{~mL}$ of $0.9 \mathrm{M}(\sim 8 \mathrm{wt} \%)$ of oxalic acid solution was added to each sludge. The mixture was digested at $80^{\circ} \mathrm{C}$ for two hours. An aliquot of the supernate was then removed from the shielded cells and analyzed by ICP-ES for the major sludge components $\mathrm{Na}, \mathrm{Fe}$ and $\mathrm{Al}$, and by ICP-MS for Tc-99. Knowing the amount of each sludge and its composition and the concentration of elements in the supernates, the fraction of Tc-99, $\mathrm{Na}, \mathrm{Fe}$, and Al dissolved could be calculated. Results are presented in Table 4-11. 
Table 4-11 Fractions (Percent) of Tc-99, Na, Al, and Fe Dissolved from Samples of Dried Sludge Digested for Two Hours with $8 \%$ Oxalic Acid at $80^{\circ} \mathrm{C}$

\begin{tabular}{||c|c|c|c|c||}
\hline SLUDGE & Na & Al & Fe & Tc-99 \\
\hline $\begin{array}{c}\text { Unwashed } \\
\text { Tank 40 (a) }\end{array}$ & $46 \%$ & $46 \%$ & $30 \%$ & $35 \%$ \\
\hline $\begin{array}{c}\text { Over Washed } \\
\text { Tank 40 (a) }\end{array}$ & $55 \%$ & $34 \%$ & $24 \%$ & $74 \%$ \\
\hline $\begin{array}{c}\text { Archived } \\
\text { Tank 11 (b) }\end{array}$ & $80 \%$ & $8.8 \%$ & $62 \%$ & $90 \%$ \\
\hline
\end{tabular}

(a) Mass of solids used was 0.21 grams. Composition of sludge solids given in Table 4-8

(b) Mass of solids used was 0.23 grams. Composition of sludge solids given in Table 4-8

(c) Mass of solids used was 0.47 grams. Composition of sludge solids was measured to be $8.9 \% \mathrm{Na}, 14.0 \% \mathrm{Al}$, $3.3 \% \mathrm{Fe}$, and $0.0011 \% \mathrm{Tc}-99$.

The results in Table 4-11clearly indicate that Tc-99 as well as Na, Al, and Fe could be dissolved from the sludges. Reasons for the large differences in the fractions of Tc-99 dissolved is not immediately apparent. But it is evident that oxalic acid, should it be used for tank cleaning, can reduce the amount of Tc-99 remaining in a tank.

Widespread use of oxalic acid in tank cleaning operations could have adverse impacts in HLW processing and downstream disposal of HLW. To minimize such impacts, the oxalic acid could be decomposed by the manganese catalyzed nitric acid reaction. This method was used in the Farea Canyon Facility to decompose the oxalic acid in the spent cleaning solutions from the Tank 16 demonstration.[29]

The Tc-99 that is not soluble in the caustic and thus in the sludge solids is probably in the +4 state in the form of $\mathrm{TcO}_{2}$. If the $\mathrm{Tc}$ could be oxidized to the +7 state to the pertechnatate anion that is soluble, more of the Tc-99 could be removed in tank cleaning. (The same is true of $\mathrm{Cr}$ where the +3 state is insoluble as $\mathrm{Cr}(\mathrm{OH}) 3$ and the +7 state is soluble as chromate.) In another study at SRTC it was shown that adding an oxidizing agent to the oxalic acid solution made it more effective in cleaning tank surfaces.[30] This study was performed with a piece of contaminated cooling coil removed from Tank 16 . Making a $4 \mathrm{wt} \%$ oxalic acid solution 0.5 vol. $\% \mathrm{H}_{2} \mathrm{O}_{2}$ increased its ability by 6 to $10 \mathrm{X}$ to dissolve radionuclides from the piece of mild steel. When the peroxide was present, the solution was more aggressive in removing beta and alpha activity from the sample. The solution also dissolved some of the mild steel of the sample. This was not excessive and it was shown that removal of $1 \mathrm{mil}$ of iron from the surface of the sample removed $96 \%$ of the radioactivity from the sample. Such corrosion would not continue very long because dissolved iron catalyzes the decomposition of the hydrogen peroxide to water and oxygen.[31] Even though Tc-99 was not specifically measured in that study, the results suggest that since the iron was removed, Tc-99 was probably removed with the rest of the beta emitters. The final surface of the coil appeared as pristine iron.

\subsection{ACKNOWLEDGEMENT}

This work was supported by Strategic Independent Research and Development funds administered by SRTC. 


\subsection{REFERENCES}

1. Parrington, J. R., Knox, H. D., Breneman, S. L., Baum, E. M. and Feiner, F., "Nuclides and Isotopes, 15th Edition, " Published by the Lockheed Martin Co. and the General Electric Co., San Jose, CA, 1996.

2. Fowler, J. R., Hamm, B. A., and Cook, J. R., "Technetium-99 in SRP High-Level Waste and Saltstone," DPST-84-334, E. I. DuPont Co., February 24, 1984.

3. Rard, J. A., "Critical Review of the Chemistry and Thermodynamics of Technetium and Some of Its Inorganic Compounds and Aqueous Species, ”URCL-53440, Lawrence Livermore National Laboratory, Livermore, CA, 1983.

4. Office of Environmental Restoration and Waste Management, "Waste Acceptance Product Specifications for Vitrified High-Level Waste Forms", USDOE Document DOE/EM-0093, Rev. 2, (12/96).

5. Barnes, M. J. and R. A. Peterson, "Excess Sodium Tetraphenylborate and Intermediates Decomposition Studies ," WSRC-TR-1998-00099, Rev. 1, October, 1998.

6. Fowler, J. R. and Eibling, R. E., "Revision of Distribution of Radionuclides between the Soluble and Insoluble Fraction of In-Tank Waste, ” DPST-81-899, E. I. DuPont Co., November 25, 1981

7. Fellinger, T. L, Bibler, N. E., and J. R. Harbour., "Characterization of and Waste Acceptance Radionuclides to be Reported For DWPF Macro Batch 2 (ESP 215-ESP 221)," WSRC-RP-99-00436, Rev 1, March, 2004.

8. Fellinger, T. L, Pareizs, J. M. Bibler, N. E., Cozzi, A. D., and Crawford, C. L., "Confirmation Run of the DWPF SRAT Cycle using the Sludge-Only Flowsheet with Tank 40 Radioactive Sludge and Frit 200 in the Shielded Cells Facility", WSRC-TR-2002-00076, Rev. 0, May 2002.

9. Bibler, N. E., "Major Elemental Composition of the First Three Tank 7 Samples, Rev.0," SRT-ITB-2003-00017, March, 2003.

10. Coleman, C. J., "Aqua Regia Dissolution of Sludge for Elemental Analysis (U)”, ADS Procedure, ADS-2226, Rev. 5, September 30, 1998.

11. Friedlander, G. and Kennedy, J. W., "Nuclear and Radiochemistry," John Wiley \& Sons, Ins., New York, p. 76, 2nd. Ed., 1955.

12. Bibler, N. E., Kinard, W. F., Dewberry, R. A., and Coleman, C. J. “A Method for the Determination of Waste Acceptance Radionuclides in DWPF Glass and Demonstration of that Method Using SRS Tank 51 Radioactive Sludge and Glass (U)", WSRC-TR-94-0505, Rev.0, October 20, 1994. 
13. Bibler, N. E., Kinard, W. F., Boyce, W.T. and Coleman, C. J. "Determination of Long Lived Fission Products and Actinides in Savannah River Site HLW Sludge and Glass for Waste Acceptance”, Journal of Radioanalytical and Nuclear Chemistry, Vol. 234, p.159-163 (1998).

14. Bibler, N. E., Coleman, C. J., and Kinard, W. F, "Relative Yields of U-235 Fission Products Measured in a High Level Waste Sludge at Savannah River Site”, Nuclear and Hazardous Waste Management, Spectrum “92, American Nuclear Society, Inc., LaGrange, IL., (1992), 952.

15. Kinard, W. F, Bibler, N. E., Coleman, C. J. and Wyrick, S.B. "Inductively Coupled PlasmaMass Spectroscopy Studies of the Chemistry of Fission Products and Actinides in High Level Waste: Lessons that can be Applied to Environmental Measurements", Radiochimica. Acta., 66/67, p.259, (1994).

16. Bibler, N. E., and Hay, M. S., "Total and Soluble Sulfur in a Sample from Tank 40 (Sludge Batch 2) and a Composite of Samples from Tank 1 (Sludge Batch 3)”, WSRC-TR-200400092, Re. 0, March, 2004.

17. Hobbs, D. T., "Precipitation of Uranium and Plutonium from Alkaline Salt Solutions," Nuclear Technology, Vol. 128, pp. 103-112, (1999).

18. Pareizs, J. M., "Washing Demonstration using Nonradioactive Simulated Tank 7 SludgeSlurry,” WSRC-TR-2002-00450, November, 2002.

19. Kolthoff, I. M. and Sandell, E. B., “Textbook of Quantitative Inorganic Analysis,” page 255, The Macmillan Co. NY, 1959.

20. Hay, M. S. and Bibler, N. E., "A Laboratory Study of Washing SRS High-Level Radioactive Sludge - Evidence for Insoluble Sodium and Cs-137, " Proceedings of the International Topical Meeting on Nuclear and Hazardous Waste Management, Spectrum '94, pages 828832, American Nuclear Soc., La Grange Park, IL, 1994.

21. Vida, J., "The Chemical Behavior of Technetium During the Treatment of High-Level Radioactive Waste," KfK 4642, Translated by J. R. Jewett, PNL-TR-497, Westinghouse Hanford Co., June, 1994.

22. Bibler, N. E., Fellinger, T. L., Marra, S. L., O’Driscoll, R. J., Ray, J. W., and Boyce, W. T., "Tc-99 and Cs-137 Volatility from the DWPF Production Melter During Vitrification of the First Macrobatch of HLW Sludge at the Savannah River Site, ” Mat. Res. Symp. Proc., Vol 606, pp. 697-702, 2000.

23. Edwards, T. B., “A Statistical Review of Analytical Laboratory Measurements.from DWPF's Macrobatch 1 and Macrobatch 2," WSRC-TR-2003-00045, Rev. 0, January, 2003. 
24. Bibler, N. E., "Characterization of Three Samples Taken From the Off Gas System of DWPF Melter One," WSRC-TR-2003-00423, Rev. 0, September, 2003.

25. Adu-Wusu, K., Barnes, M. J., Bibler, N. E., et al., “Waste Tank Heel Chemical Cleaning Summary,” WSRC-TR-2003-00401, September, 2003.

26. Bechtold, D. B., et al., "Laboratory Testing of Oxalic Acid Dissolution of Tank 241-C-106 Sludge,” RPP-17158, Rev.0, Fluor Hanford, Richland, WA 99352, July, 2003.

27. Fong, M. C. H., “Oxalic Acid Cleaning of Tank 24H,” DPST-85-782, September, 1985.

28. West, W. L., "Tank 16 Demonstration -Water Wash and Chemical Cleaning Results," DPSP-80-17-23, December, 1980.

29. Bibler, N. E., Hoisington, J. E., and Holtzscheiter, E. W., "Technical Data Summary: Decomposition of Oxalic Acid by the Manganese Catalyzed Nitric Acid Reaction," DPSTD80-36, March, 1981.

30. Bibler, N. E., " $\mathrm{H}_{2} \mathrm{O}_{2}-\mathrm{H}_{2} \mathrm{C}_{2} \mathrm{O}_{4}$ Solutions for Cleaning Inside Surfaces of SRP Waste Tanks," DPST-81-308, March, 1981.

31. Schumb, W. C., "Hydrogen Peroxide” American Chemical Society Monograph, Reinhold Publishing Co., New York (1955). 